\title{
Weak global sensitivity of cloud condensation nuclei and the aerosol indirect effect to Criegee $+\mathrm{SO}_{2}$ chemistry
}

\author{
J. R. Pierce ${ }^{1,2}$, M. J. Evans ${ }^{3,4}$, C. E. Scott ${ }^{5}$, S. D. D’Andrea ${ }^{2,1}$, D. K. Farmer ${ }^{6}$, E. Swietlicki ${ }^{7}$, and D. V. Spracklen ${ }^{5}$ \\ ${ }^{1}$ Department of Atmospheric Science, Colorado State University, Ft. Collins, CO, USA \\ ${ }^{2}$ Department of Physics and Atmospheric Science, Dalhousie University, Halifax, NS, Canada \\ ${ }^{3}$ National Centre for Atmospheric Science, University of York, York, UK \\ ${ }^{4}$ Department of Chemistry, University of York, York, UK \\ ${ }^{5}$ School of Earth and Environment, University of Leeds, Leeds, UK \\ ${ }^{6}$ Department of Chemistry, Colorado State University, Ft. Collins, CO, USA \\ ${ }^{7}$ Division of Nuclear Physics, Lund University, Lund, Sweden
}

Correspondence to: J. R. Pierce (jeffrey.robert.pierce@gmail.com)

Received: 7 December 2012 - Published in Atmos. Chem. Phys. Discuss.: 20 December 2012

Revised: 27 February 2013 - Accepted: 4 March 2013 - Published: 15 March 2013

\begin{abstract}
H}_{2} \mathrm{SO}_{4}$ vapor is important for the nucleation of atmospheric aerosols and the growth of ultrafine particles to cloud condensation nuclei (CCN) sizes with important roles in the global aerosol budget and hence planetary radiative forcing. Recent studies have found that reactions of stabilized Criegee intermediates (CIs, formed from the ozonolysis of alkenes) with $\mathrm{SO}_{2}$ may be an important source of $\mathrm{H}_{2} \mathrm{SO}_{4}$ that has been missing from atmospheric aerosol models. For the first time in a global model, we investigate the impact of this new source of $\mathrm{H}_{2} \mathrm{SO}_{4}$ in the atmosphere. We use the chemical transport model, GEOS-Chem, with the online aerosol microphysics module, TOMAS, to estimate the possible impact of CIs on present-day $\mathrm{H}_{2} \mathrm{SO}_{4}, \mathrm{CCN}$, and the cloud-albedo aerosol indirect effect (AIE). We extend the standard GEOSChem chemistry with CI-forming reactions (ozonolysis of isoprene, methyl vinyl ketone, methacrolein, propene, and monoterpenes) from the Master Chemical Mechanism. Using a fast rate constant for $\mathrm{CI}+\mathrm{SO}_{2}$, we find that the addition of this chemistry increases the global production of $\mathrm{H}_{2} \mathrm{SO}_{4}$ by $4 \% . \mathrm{H}_{2} \mathrm{SO}_{4}$ concentrations increase by over $100 \%$ in forested tropical boundary layers and by over 10-25\% in forested $\mathrm{NH}$ boundary layers (up to $100 \%$ in July) due to $\mathrm{CI}+\mathrm{SO}_{2}$ chemistry, but the change is generally negligible elsewhere. The predicted changes in $\mathrm{CCN}$ were strongly dampened to the $\mathrm{CI}+\mathrm{SO}_{2}$ changes in $\mathrm{H}_{2} \mathrm{SO}_{4}$ in some regions: less than $15 \%$ in tropical forests and less than $2 \%$ in most mid-latitude locations. The global-mean $\mathrm{CCN}$ change
\end{abstract}

was less than $1 \%$ both in the boundary layer and the free troposphere. The associated cloud-albedo AIE change was less than $0.03 \mathrm{~W} \mathrm{~m}^{-2}$. The model global sensitivity of $\mathrm{CCN}$ and the AIE to $\mathrm{CI}+\mathrm{SO}_{2}$ chemistry is significantly (approximately one order-of-magnitude) smaller than the sensitivity of $\mathrm{CCN}$ and AIE to other uncertain model inputs, such as nucleation mechanisms, primary emissions, SOA (secondary organic aerosol) and deposition. Similarly, comparisons to size-distribution measurements show that uncertainties in other model parameters dominate model biases in the modelpredicted size distributions. We conclude that improvement in the modeled $\mathrm{CI}+\mathrm{SO}_{2}$ chemistry would not likely lead to significant improvements in present-day $\mathrm{CCN}$ and AIE predictions.

\section{Introduction}

Atmospheric aerosol particles regulate climate by scatting/absorbing sunlight (aerosol direct effect on climate) (Charlson et al., 1992) and by acting as cloud condensation nuclei (CCN) and affecting cloud albedo and lifetime (aerosol indirect effects, AIEs) (Albrecht, 1989; Twomey, 1974). These aerosol/climate effects, in particular the AIEs, represent the largest uncertainties in the radiative forcing change between 1750 and 2000 as quantified by the Intergovernmental Panel on Climate Change (Forster et al., 2007). 
The uncertainties in the indirect effect are due, in part, to uncertainties in the processes that shape $\mathrm{CCN}$ in global aerosol predictions.

CCN represent the subset of atmospheric aerosols on which cloud droplets may form. Whether or not a particle acts as a CCN in a cloud depends on the maximum supersaturation in the cloud, as well as the size and composition of the particle. Typically, particles must have dry diameters $>30-100 \mathrm{~nm}$ to act as $\mathrm{CCN}$, with smaller particles activating if there is a strong cloud updraft and if the particle is hygroscopic (Nenes and Seinfeld, 2003; Petters and Kreidenweis, 2007). CCN are created when (1) particles of CCN size/hygroscopicity are emitted directly to the atmosphere, (2) particles are emitted at sizes too small to act as CCN but grow to CCN size through condensation of vapors (generally sulfuric acid and organics), or (3) nucleation of $\sim 1 \mathrm{~nm}$ particles occurs (via clustering of sulfuric acid and likely organic $\mathrm{NH}_{3}$ and $\mathrm{H}_{2} \mathrm{O}$ molecules), with these particles also growing via condensation to $\mathrm{CCN}$ sizes (Merikanto et al., 2009; Pierce and Adams, 2009c). However, not all ultrafine ( $D_{\mathrm{p}}$ $<100 \mathrm{~nm}$ ) particles will survive to grow to $\mathrm{CCN}$-sized particles as many will be lost by coagulation before reaching $\mathrm{CCN}$ sizes (Pierce and Adams, 2007). Thus, the balance of emissions, nucleation, condensational growth and coagulational losses must be accurately represented in models in order to predict CCN.

Sulfuric acid $\left(\mathrm{H}_{2} \mathrm{SO}_{4}\right)$ vapor is a key component of $\mathrm{CCN}$ creation as it contributes to both aerosol nucleation and the growth of the ultrafine particles to CCN sizes (Kulmala et al., 2004). While $\mathrm{H}_{2} \mathrm{SO}_{4}$ is not the only species involved in tropospheric nucleation, nucleation rates measured in all parts of the troposphere have been shown to have at least linear dependence on $\mathrm{H}_{2} \mathrm{SO}_{4}$ concentrations (e.g. Sihto et al., 2006). In many locations, such as the polluted boundary layer, remote oceans and the free troposphere, $\mathrm{H}_{2} \mathrm{SO}_{4}$ may be a dominant species in aerosol growth (Jung et al., 2006), although organic condensation may dominate in many continental regions (Jimenez et al., 2009; Riipinen et al., 2011). Thus, uncertainties in the production of $\mathrm{H}_{2} \mathrm{SO}_{4}$ vapor (via gas phase oxidation of $\mathrm{SO}_{2}$ ) may lead to uncertainties in $\mathrm{CCN}$ predictions.

$\mathrm{SO}_{2}$, the precursor of $\mathrm{H}_{2} \mathrm{SO}_{4}$ vapor, has three dominant fates in the atmosphere: (1) it may be removed from the atmosphere through dry or wet deposition without any chemical transformation in the atmosphere, (2) it may be oxidized by $\mathrm{H}_{2} \mathrm{O}_{2}$ or $\mathrm{O}_{3}$ in cloud water to form condensed sulfate, or (3) it may be oxidized in the gas phase (traditionally in models this is only by $\mathrm{OH}$ ) to form $\mathrm{H}_{2} \mathrm{SO}_{4}$ vapor, which will participate in aerosol nucleation or condensation as described earlier. Models generally agree that the deposition is the dominant pathway globally followed by aqueous chemistry, then gas-phase chemistry, and the gas-phase chemistry pathway has been predicted to contribute $5-18 \%$ of the loss of $\mathrm{SO}_{2}$ (Berglen et al., 2004; Chin et al., 1996; Koch et al., 1999; Sofen et al., 2011). Thus, there are uncertainties in the production of $\mathrm{H}_{2} \mathrm{SO}_{4}$ vapors in models that may lead to errors in the aerosol microphysical processes associated with $\mathrm{H}_{2} \mathrm{SO}_{4}$.

Traditionally, the sole pathway of $\mathrm{H}_{2} \mathrm{SO}_{4}$ vapor production in models was via the reaction of $\mathrm{SO}_{2}$ gas with the hydroxyl radical $\mathrm{OH}$ (e.g. Berglen et al., 2004; Chin et al., 1996; Koch et al., 1999; Sofen et al., 2011). However, there has recently been much attention given to the reaction of $\mathrm{SO}_{2}$ with stabilized Criegee intermediates (CIs) (Boy et al., 2012; Mauldin et al., 2012; Vereecken et al., 2012; Welz et al., 2012). (Throughout this paper, we will abbreviate the stabilized Criegee intermediates as simply "CIs". When discussing the energetic Criegee intermediate, which may either decompose or stabilize (by collision with $\mathrm{O}_{2}$ or $\mathrm{N}_{2}$ ), we will explicitly state that it is the energetic Criegee.) The $\mathrm{CI}+\mathrm{SO}_{2}$ reaction has gained much attention because of the possibility of these reactions creating $\mathrm{H}_{2} \mathrm{SO}_{4}$. CIs are zwitterions of carbonyl oxides that are formed during ozonolysis of alkenes. Because there are many different alkenes emitted to the atmosphere, there are many different potential CIs relevant to the atmosphere. As alkenes tend to be short-lived in the atmosphere ( $\sim$ hours), the CIs will be limited to alkene source regions, such as the vegetated continental boundary layer (particularly tropical, broad-leaf and boreal forests) and regions with anthropogenic VOC emissions.

The chemical loss of the CIs is dominated by reaction with water vapor. The CIs can potentially also react with other compounds such as $\mathrm{CO}, \mathrm{SO}_{2}, \mathrm{NO}, \mathrm{NO}_{2}$, but based on previous rate-constant evaluations, these routes were not considered important oxidation pathways for most atmospheric modeling studies. However, the recent study of Welz et al. (2012) showed that the reaction of a $\mathrm{CI}, \mathrm{H}_{2} \mathrm{COO}$, with $\mathrm{SO}_{2}$ and $\mathrm{NO}_{2}$ was significantly faster $\left(3.9 \times 10^{-11}\right.$ and $7.0 \times 10^{-12} \mathrm{~cm}^{3} \mathrm{~s}^{-1}$, respectively) than previously considered (e.g. $7.0 \times 10^{-14}$ and $1 \times 10^{-15} \mathrm{~cm}^{3} \mathrm{~s}^{-1}$, Jenkin et al., 1997). These reaction rates published by Welz et al. (2012) suggest that the CI could be an additional important oxidant for $\mathrm{SO}_{2}$ in regions with alkene emissions. Although significant, the study of Welz et al. (2012) left several unresolved issues. The rates were only measured for the smallest CI, $\mathrm{H}_{2} \mathrm{COO}$, leaving the potential for different CIs to react at different rates. Additionally, the study was also done at low pressure (4 Torr), making it unclear if this rate constant is appropriate for atmospheric conditions.

Independently, Mauldin et al. (2012) found that they needed an additional oxidant of $\mathrm{SO}_{2}$ to reach closure for $\mathrm{H}_{2} \mathrm{SO}_{4}$ concentrations. They also found that this additional oxidant was strongly enhanced by the presence of emissions from vegetation, to which they concluded that the alkenes from the vegetation (mostly isoprene and various monoterpenes, such as $\alpha$-pinene) enhanced the production of CIs and $\mathrm{H}_{2} \mathrm{SO}_{4}$. Mauldin et al. (2012) deduced that the reaction rate constants of $\mathrm{SO}_{2}$ with CIs from ozonolysis of $\alpha$-pinene and limonene were $6 \times 10^{-13} \mathrm{~cm}^{3} \mathrm{~s}^{-1}$ and $8 \times 10^{-13} \mathrm{~cm}^{3} \mathrm{~s}^{-1}$, respectively, under boundary-layer atmospheric conditions. 
While slower than the rates found in Welz et al. (2012), these rates are still about 1 order-of-magnitude faster than previously used (e.g. $7.0 \times 10^{-14} \mathrm{~cm}^{3} \mathrm{~s}^{-1}$, Jenkin et al., 1997). A recent study by Boy et al. (2012) used measurements and modeling of Hyytiälä, Finland, and Hohenpeissenberg, Germany, to determine the importance of CIs for $\mathrm{SO}_{2}$ oxidation and $\mathrm{H}_{2} \mathrm{SO}_{4}$ formation at these sites. When using the rate coefficients estimated in the Mauldin et al. (2012) and Welz et al. (2012) studies, they found that the CIs could be responsible for up to $50 \%$ of $\mathrm{SO}_{2}$ oxidation at these locations.

Theoretical calculations of the reaction of CIs with $\mathrm{SO}_{2}$ by Vereecken et al. (2012) showed that while smaller CIs (e.g. $\mathrm{H}_{2} \mathrm{COO}$ ) produce $\mathrm{H}_{2} \mathrm{SO}_{4}$ from the reaction with $\mathrm{SO}_{2}$, larger CIs (such as those that may be produced from typical alkenes in the atmosphere) may produce stable sulfur-bearing secondary ozonides (i.e. the $\mathrm{SO}_{2}$ sticks to the $\mathrm{CI}$ ). Although entirely speculative at this point, these sulfur-bearing secondary ozonides may have low volatilities and may be a possible reaction in the enhancement of biogenic SOA (secondary organic aerosol) by anthropogenic pollution (e.g. Spracklen et al., 2011b).

Thus, there are still large uncertainties regarding $\mathrm{CI}+\mathrm{SO}_{2}$ chemistry. The theoretical findings of Vereecken et al. (2012) conflict with the measurements of Mauldin et al. (2012), and the $\mathrm{CI}+\mathrm{SO}_{2}$ rate constants derived from the larger alkenes in Mauldin et al. (2012) are over 1 order-of-magnitude slower than the rate constants measured for $\mathrm{H}_{2} \mathrm{COO}$ by Welz et al. (2012). However, while these uncertainties in $\mathrm{CI}+\mathrm{SO}_{2}$ chemistry persist, scoping studies of the potential importance of CI chemistry on CCN and climate can be performed to determine how critical these $\mathrm{CI}+\mathrm{SO}_{2}$ reactions may be.

In this paper, we attempt to provide an upper bound for the potential of $\mathrm{CI}+\mathrm{SO}_{2} \rightarrow \mathrm{H}_{2} \mathrm{SO}_{4}$ chemistry to enhance $\mathrm{CCN}$ concentrations and the cloud albedo AIE in a global chemical transport model with online aerosol microphysics. Our goal is to determine if the $\mathrm{CI}+\mathrm{SO}_{2}$ reactions may have an appreciable effect on CCN/AIE predictions and to provide recommendations for future measurements. The following section provides an overview of the model used in this study. The results and conclusions follow in Sects. 3 and 4.

\section{Methods}

In this paper, we use GEOS-Chem-TOMAS, a global chemical transport model with online aerosol microphysics. GEOS-Chem-TOMAS uses GEOS-Chem v8.02.02 (http:// www.geos-chem.org), and has $4^{\circ} \times 5^{\circ}$ horizontal resolution as well as 30 vertical layers from the surface to $0.01 \mathrm{hPa}$. Limitations due to the model resolution are discussed in the conclusions. Meteorological inputs are from the GEOS3 reanalysis (http://gmao.gsfc.nasa.gov).

GEOS-Chem was extended with the TOMAS aerosol module (Adams and Seinfeld, 2002; Lee and Adams, 2010; Lee et al., 2009; Pierce and Adams, 2006, 2009a, b, c; Pierce et al., 2007, 2009; Snow-Kropla et al., 2011; Trivitayanurak et al., 2008; Westervelt et al., 2012). This version of TOMAS simulates the aerosol size distribution using 40 size sections ranging from $1 \mathrm{~nm}$ to $10 \mu \mathrm{m}$. In TOMAS, we simulate sulfate, sea-salt, organic carbon, black carbon and dust. In our base-case simulations, secondary organic aerosol (SOA) is formed from terrestrial biogenic sources only. The biogenic SOA source is $10 \%$ of monoterpene emissions, and represents an annual flux of $18 \mathrm{Tg} \mathrm{yr}^{-1}$. In this paper, we perform sensitivity studies where we add $100 \mathrm{Tg} \mathrm{yr}^{-1}$ of additional SOA that is correlated with CO based on the findings of Spracklen et al. (2011b). This additional SOA is used as a sensitivity case because the efficacy of nucleated particles forming CCN depends on the rate of SOA condensation (Pierce and Adams, 2009c; Riipinen et al., 2011; Spracklen et al., 2008). SOA is assumed to be non-volatile and is distributed across the aerosol size distribution proportionally to the Fuchs-corrected aerosol surface area (Pierce et al., 2011; Riipinen et al., 2011). Nucleation in these simulations is the binary scheme of Vehkamäki et al. (2002), and we use activation nucleation (Sihto et al., 2006) in the boundary layer with an A-factor of $2 \times 10^{-6} \mathrm{~s}^{-1}$ (Spracklen et al., 2008). Nucleation, growth and $\mathrm{CCN}$ formation rates in this version of the model were tested against observations at 5 locations in Westervelt et al. (2012). Details on emissions in GEOSChem are found in Van Donkelaar et al. (2008).

We calculate the first aerosol indirect effect (AIE), or cloud albedo effect, using the offline version of the Edwards and Slingo (1996) radiative transfer model. Our method is described in detail in Spracklen et al. (2011a); the fractional change in cloud droplet number concentration (CDNC) between two simulations is used to perturb the effective radii of cloud droplets in the radiative transfer model. To determine the AIE, net radiative fluxes at the top of the atmosphere are then compared to those obtained from a control experiment with no perturbation to cloud droplet effective radii. CDNC are calculated using the aerosol size distributions predicted by the GEOS-Chem-TOMAS simulations along with a mechanistic parameterization of cloud drop formation (Nenes and Seinfeld, 2003). As a base assumption, we assume a uniform updraft velocity of $0.2 \mathrm{~m} \mathrm{~s}^{-1}$, but test values between 0.1 and $0.5 \mathrm{~m} \mathrm{~s}^{-1}$ to examine the sensitivity of the AIE to this assumption. We employ a 1983-2008 multiannual mean cloud climatology from the International Satellite Cloud Climatology Project (ISCCP). Rap et al. (2013) found a low sensitivity to the cloud climatology used when comparing the AIE obtained using cloud fields for a single year to the AIE obtained when a multi-annual mean cloud climatology is used (Table A1, Rap et al., 2013). As we only quantify the cloud albedo AIE sensitivity to $\mathrm{CI}+\mathrm{SO}_{2}$ chemistry, the total AIE (when cloud lifetime effects are included) may be larger.

We updated the standard GEOS-Chem alkene- $\mathrm{O}_{3}$ chemistry scheme following the methodology used in the Master Chemical Mechanism (MCM) (Jenkin et al., 1997) (http: 
Table 1. Overview of the GEOS-Chem-TOMAS simulations performed in this study.

\begin{tabular}{lcc}
\hline Simulation name & $\mathrm{CI}+\mathrm{SO}_{2}$ & Extra $100 \mathrm{Tg} \mathrm{SOA} \mathrm{yr}^{-1}$ \\
\hline BASE & no & no \\
BASE-CI & yes & no \\
XSOA & no & yes \\
XSOA-CI & yes & yes \\
\hline
\end{tabular}

$/ / \mathrm{mcm}$.leeds.ac.uk) for propene and isoprene (the only primary emitted compounds with double bonds considered by the standard GEOS-Chem chemistry scheme) and for methyl vinyl ketone (MVK) and methacrolein (MACR) (isoprene degradation products). Additionally, we added the initial oxidations steps $\left(\mathrm{OH}, \mathrm{NO}_{3}\right.$ and $\left.\mathrm{O}_{3}\right)$ of monoterpene chemistry into the scheme (monoterpenes are used for SOA in standard GEOS-Chem simulations but not considered in the standard gas-phase chemistry scheme), and we treat the chemistry for all monoterpenes as if they are $\alpha$-pinene (the dominant monoterpene). The initial ozonolysis of each of these compounds (isoprene, MVK, MACR, propene and monoterpenes) results in a primary, energetic Criegee intermediate, which may either decompose or form a stabilized Criegee intermediate. The net reactions to form the stabilized Criegee intermediates are shown in Table 2. These stabilized Criegee radicals (CIs) then react with $\mathrm{CO}, \mathrm{NO}, \mathrm{NO}_{2}, \mathrm{SO}_{2}$ and water vapor to form stable products. The rates constants for $\mathrm{CO}$ and $\mathrm{NO}$ are taken from the MCM and are $1.2 \times 10^{-15}$ and $1.00 \times 10^{-14}$, respectively, for all CIs. The rate constant for reaction with water vapor is again taken from the MCM and depends upon the structure of the Criegee radical and varies from $6 \times 10^{-18} \mathrm{~cm}^{3} \mathrm{~s}^{-1}$ to $1.6 \times 10^{-17}$. For $\mathrm{SO}_{2}$ and $\mathrm{NO}_{2}$, we use the fast CI oxidation rates of $3.9 \times 10^{-11}$ and $7.0 \times 10^{-12} \mathrm{~cm}^{3} \mathrm{~s}^{-1}$, respectively, from Welz et al. (2012) for all CIs. This rate constant for $\mathrm{SO}_{2}$ allows us to determine a probable upper bound for the impact of CI chemistry on $\mathrm{CCN}$ and the aerosol indirect effect.

Each model simulation was run for 13 months (1 December 2000-1 January 2002) from a pre-spun-up restart file. The first month of the simulation was used as additional spinup to let the different simulations tested here diverge.

\section{Overview of simulations}

Table 1 shows an overview of the four GEOS-Chem-TOMAS simulations performed in this study. The two BASE simulations include only biogenic SOA, while the two XSOA simulations include an extra $100 \mathrm{Tg} \mathrm{SOA} \mathrm{yr}^{-1}$ that is correlated with anthropogenic CO emissions based on Spracklen et al. (2011b). The XSOA cases allow us to determine if the effect of the extra $\mathrm{H}_{2} \mathrm{SO}_{4}$ formed by $\mathrm{CI}+\mathrm{SO}_{2}$ chemistry on $\mathrm{CCN}$ is stronger/weaker in the presence of extra SOA, which is a major uncertainty in global aerosol models. The extra SOA in the XSOA cases is added as condensable material in
Table 2. Sources and sinks of CIs in the BASE-CI and XSOA-CI simulations (same for both simulations).

\begin{tabular}{ll}
\hline Sources of CIs & $\begin{array}{l}\text { Rate } \\
{\left[\mathrm{Gmol} \mathrm{yr}^{-1}\right]}\end{array}$ \\
\hline $\mathrm{ISOP}+\mathrm{O}_{3} \rightarrow \mathrm{MACROO}$ & 48.4 \\
$\mathrm{ISOP}+\mathrm{O}_{3} \rightarrow \mathrm{MVKOO}$ & 32.2 \\
$\mathrm{MACR}, \mathrm{MVK}+\mathrm{O}_{3} \rightarrow \mathrm{MGLOO}$ & 21.8 \\
$\mathrm{PRPE}+\mathrm{O}_{3} \rightarrow \mathrm{CH}_{3} \mathrm{CHOO}$ & 21.5 \\
$\mathrm{ISOP}, \mathrm{MACR}, \mathrm{MVK}, \mathrm{PRPE}+\mathrm{O}_{3} \rightarrow \mathrm{CH}_{2} \mathrm{OO}$ & 137.7 \\
$* \mathrm{MO}+\mathrm{O}_{3} \rightarrow \mathrm{APINOO}$ & 85.2 \\
Total sources & 346.8 \\
\hline $\mathrm{Sinks}$ of $\mathrm{CIs}$ & Rate \\
& {$[\mathrm{Gmol} \mathrm{yr}-1]$} \\
\hline $\mathrm{CI}+\mathrm{CO}$ & 0.326 \\
$\mathrm{CI}+\mathrm{NO}_{\mathrm{CI}}+\mathrm{NO}_{2}$ & 0.00072 \\
$\mathrm{CI}+\mathrm{H}_{2} \mathrm{O}$ & 1.44 \\
$\mathrm{CI}+\mathrm{SO}_{2}$ & 335.0 \\
Total sinks & 10.05 \\
\hline
\end{tabular}

ISOP $=$ isoprene, $\mathrm{MACR}=$ methacrolein, $\mathrm{MVK}=$ mthyl vinyl ketone, $\mathrm{MGL}=$ methylglyoxal, $\mathrm{PRPE}=$ propene, $\mathrm{MO}=$ all monoterpenes, $\mathrm{APIN}=\alpha$-pinene, $\mathrm{CIs}$ end in "OO".

${ }^{*}$ Criegees from all monoterpenes are assumed to take the form of the $\alpha$-pinene criegee.

the grid boxes where $\mathrm{CO}$ is emitted. This extra SOA does not contribute to additional CI formation or alter the gasphase chemistry scheme in any way. The simulations without "CI" in their name do not include $\mathrm{CI}+\mathrm{SO}_{2}$ chemistry, and the simulations with "CI" in the name do include this chemistry. The BASE-CI and XSOA-CI simulations use the fast $\mathrm{CI}+\mathrm{SO}_{2}$ rate constant found by Welz et al. (2012), which are over 1 order-of-magnitude larger than those found by Mauldin et al. (2012) and over 2 orders-of-magnitude faster than those used in MCM. The Welz et al. (2012) rate constant is used for all CIs simulated in the model, and it allows us to provide an upper bound for the $\mathrm{CCN}$ impacts of $\mathrm{CI}+\mathrm{SO}_{2} \rightarrow \mathrm{H}_{2} \mathrm{SO}_{4}$ chemistry. Because the extra SOA in the XSOA cases have no impact on the CI chemistry, the BASE$\mathrm{CI}$ and XSOA-CI cases have the same CI budgets (described in the next section).

\section{Results}

\subsection{Criegee intermediate budget}

Table 2 shows the sources and sinks of CIs in the BBASECI (and the XSOA-CI) simulations. About $62 \%$ of the CI molecules are formed from the ozonolysis of isoprene (including CIs from the ozonolysis of isoprene products, methyl vinyl ketone (MVK) and methacrolein (MACR)). The ozonolysis of monoterpenes is responsible for about $25 \%$ of the CIs, and the rest (13\%) is from the ozonolysis 


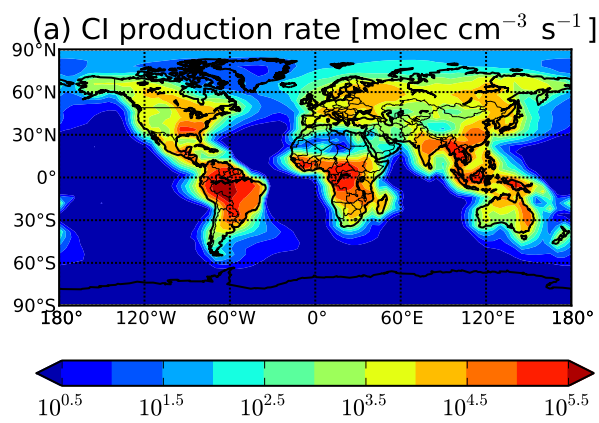

(b) Fraction of $\mathrm{Cl}$ loss by $\mathrm{SO}_{2}[\%]$

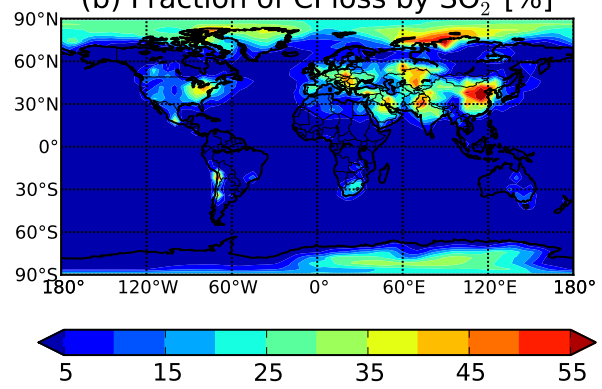

Fig. 1. (a) The annual-average boundary-layer production rate of CIs in the BBASE-CI (and XSOA-CI, same for both simulations) simulation. (b) The annual-average fraction of CI loss via reaction with $\mathrm{SO}_{2}$ in the same simulation in the boundary layer.

of propene. In the calculation of these fractions we have assumed that isoprene (and MVK and MACR) accounts for $83 \%$ of $\mathrm{CH}_{2} \mathrm{OO}$ production and propene for $17 \%$ of $\mathrm{CH}_{2} \mathrm{OO}$ production (this is the same ratio as isoprene (and MVK and MACR) versus propene forming other CIs (i.e. $\mathrm{MACROO}+\mathrm{MVKOO}+\mathrm{MGLOO}$ versus $\left.\mathrm{CH}_{3} \mathrm{CHOO}\right)$ ).

Globally, the loss of CIs in our model is dominated $(\sim 96.6 \%)$ by reaction with water vapor (Table 2$)$. Reaction with $\mathrm{SO}_{2}$ represents $2.9 \%$ of the CI loss, and the total summed loss by reaction with $\mathrm{CO}, \mathrm{NO}$ and $\mathrm{NO}_{2}$ is $0.5 \%$. In our simulations, we use the fast $\mathrm{CI}+\mathrm{SO}_{2}$ and $\mathrm{CI}+\mathrm{NO}_{2}$ reaction rates presented in Welz et al. (2012) for all CIs. This $\mathrm{CI}+\mathrm{SO}_{2}$ rate constant is over 1 order-of-magnitude faster than the rate constants published in Mauldin et al. (2012) and over 2 orders-of-magnitude faster than what is currently used in the MCM (Jenkin et al., 1997). Thus, the CI loss by reaction with water vapor could be over $99 \%$ of the total CI loss if the slower reaction rates were used. However, the $\mathrm{CI}+\mathrm{H}_{2} \mathrm{O}$ rate constant is also highly uncertain with significant differences (about a factor of 10) between studies (Calvert et al., 2000); thus, the rate of even this dominant sink processes for CIs is currently highly uncertain.

Figure 1a shows the annual-average boundary-layer production rate of CIs in the BASE-CI (or XSOA-CI) simulation (the same in both simulations). CI production rates exceed $10^{5}$ molec $\mathrm{cm}^{-3} \mathrm{~s}^{-1}$ in the tropics and a portion of the southeastern US, and exceed $10^{4}$ molec $\mathrm{cm}^{-3} \mathrm{~s}^{-1}$ in many NH boreal and broad-leaf forest regions. Outside of CI-precursor
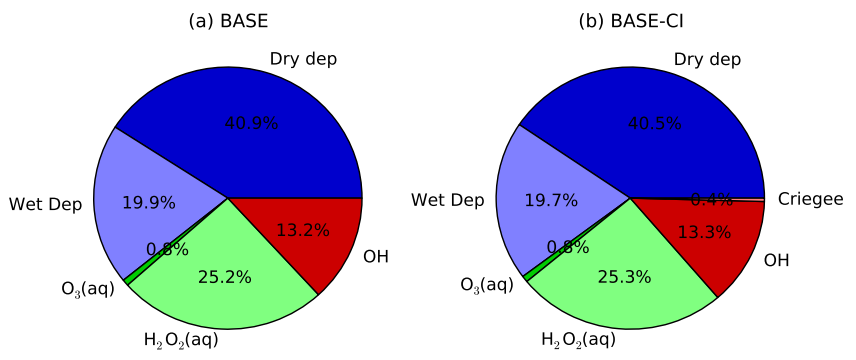

Fig. 2. Fractional contributions of $\mathrm{SO}_{2}$-loss pathways predicted for the BASE and BASE-CI simulations (XSOA and XSOA-CI simulations give the same respective $\mathrm{SO}_{2}$ budgets).

source regions (forests and industrial regions), the CI production rates are orders-of-magnitude slower due to the short chemical lifetimes of CI precursors. Figure $1 b$ shows the fraction of CI that is lost by reaction with $\mathrm{SO}_{2}$ in the boundary layer. Regions with high $\mathrm{SO}_{2}$ concentrations and/or low absolute humidities have the highest fractional loss of CIs by $\mathrm{SO}_{2}$. In the mid-latitudes, the fraction of $\mathrm{CI}$ loss by $\mathrm{SO}_{2}$ can be more important, and it exceeds $40 \%$ in several $\mathrm{SO}_{2}$-rich regions. Additionally, the poles have large regions where CI loss by reaction with $\mathrm{SO}_{2}$ exceeds $30 \%$ due to low absolute humidities. In the tropical regions, the loss of CIs is almost entirely (over $95 \%$ ) by reaction with $\mathrm{H}_{2} \mathrm{O}$ due to the high absolute humidity and generally low $\mathrm{SO}_{2}$ concentrations. Since the tropics have the highest CI production rates (Fig. 1a), the global-mean loss of CIs by reaction with $\mathrm{SO}_{2}$ is low, $2.9 \%$ (Table 2).

\subsection{Effect of CIs on $\mathrm{SO}_{2}$-loss pathways}

Figure 2 shows the global relative contributions to the various $\mathrm{SO}_{2}$-loss pathways as predicted by GEOS-Chem for the BASE and BASE-CI cases (XSOA and XSOA-CI, respectively, gave identical results). Just over $60 \%$ of $\mathrm{SO}_{2}$ is removed through deposition without any chemical loss in the atmosphere, and about two-thirds of this deposition is dry deposition. About $26 \%$ of the $\mathrm{SO}_{2}$ is removed through aqueous chemistry, and this aqueous removal is dominated by chemistry with $\mathrm{H}_{2} \mathrm{O}_{2}$. The balance of the $\mathrm{SO}_{2}$ loss (13-14\%) is via gas-phase chemistry, which in the BASE simulation is entirely through oxidation with $\mathrm{OH}$. Figure 2 shows that when Criegee chemistry is turned on in the BASE-CI case, the CIs contribute $0.4 \%$ globally to the loss of $\mathrm{SO}_{2}$ from the atmosphere. The CIs also indirectly affect the fractional $\mathrm{SO}_{2}$ loss pathways by increasing oxidant concentrations (via CI $+\mathrm{NO}_{x}$ reactions) such that the $\mathrm{OH}$ and $\mathrm{H}_{2} \mathrm{O}_{2}$ pathways each increase by $0.1 \%$. To compensate for the fractional $0.6 \%$ increase in the chemical loss of $\mathrm{SO}_{2}$ in BASE-CI, the fractional deposition pathway is reduced by $0.6 \%$. The decrease in the fractional contribution of deposition to $\mathrm{SO}_{2}$ loss is driven by a $1.2 \%$ decrease in the lifetime and burden of $\mathrm{SO}_{2}$ due to the $\mathrm{CI}+\mathrm{SO}_{2}$ chemistry. Overall, there is a net global increase 

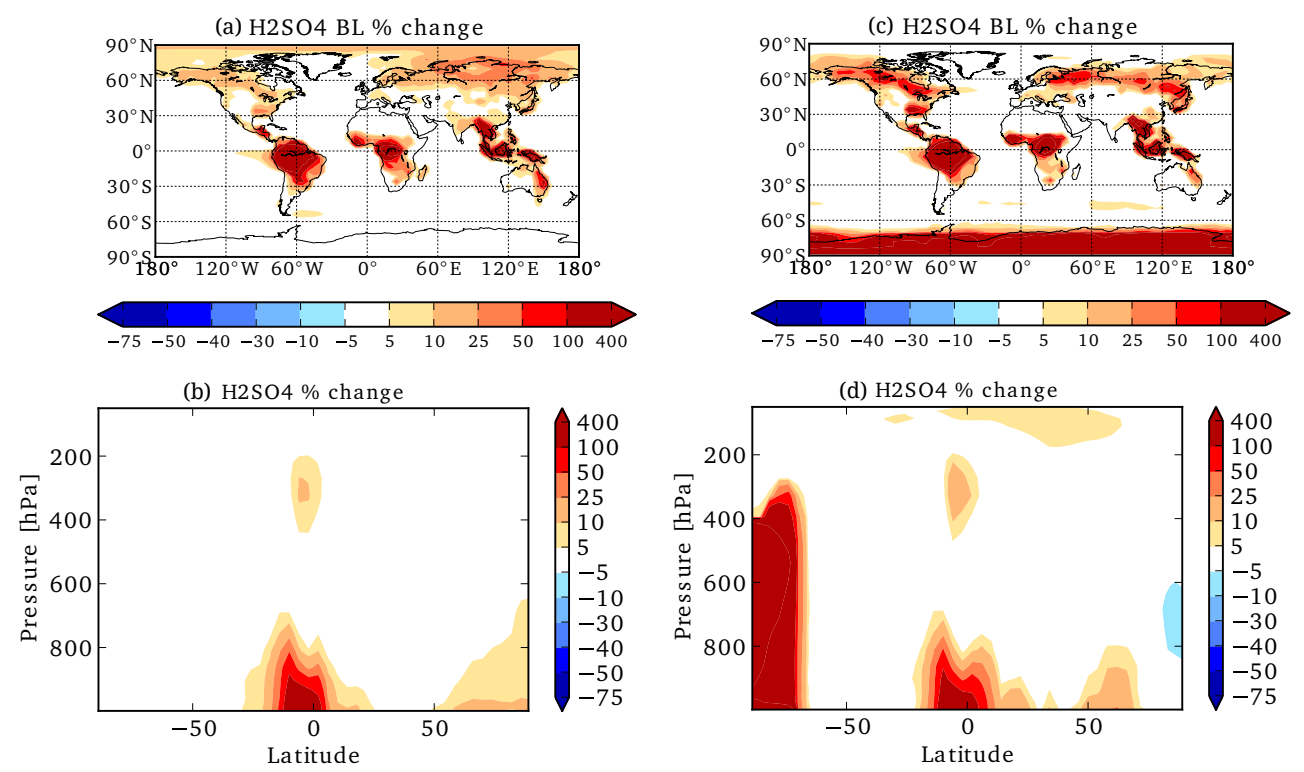

Fig. 3. Percent change in gas-phase $\mathrm{H}_{2} \mathrm{SO}_{4}$ concentration due to the addition of the $\mathrm{CI}+\mathrm{SO}_{2}$ chemistry (BASE-CI-BASE). The left column (a and $\mathbf{b}$ ) is annual-mean values, and the right column (c and $\mathbf{d}$ ) is for July. The top panels (a and c) show the boundary-layer values, and the bottom panels (b and $\mathbf{d}$ ) show zonal-mean values.

in the fraction of $\mathrm{SO}_{2}$ that forms $\mathrm{H}_{2} \mathrm{SO}_{4}$ vapor by $0.5 \%$ due to the addition of Criegee chemistry in GEOS-Chem, which corresponds to a $4 \%$ increase in the production of $\mathrm{H}_{2} \mathrm{SO}_{4}$ vapor in the model. However, the global $\mathrm{H}_{2} \mathrm{SO}_{4}$ burden increases only by $1.6 \%$ due to an increase in the condensation sink from an increase in nucleation in the BASE-CI case (these feedbacks will be discussed in the results section). This increase in $\mathrm{H}_{2} \mathrm{SO}_{4}$ production/concentration is not, however, homogeneous around the Earth due to CIs being located in several hot-spots in the continental boundary layer. The distribution of $\mathrm{H}_{2} \mathrm{SO}_{4}$ (and aerosols) will be explored next.

\subsection{CI influence on global aerosol microphysics}

Figure 3 shows the BL- and zonal-mean percent changes in the gas-phase $\mathrm{H}_{2} \mathrm{SO}_{4}$ concentrations between the BASE and BASE-CI cases (red denotes higher concentrations in the BASE-CI case) for both an annual average and the month of July (when alkene emissions from the Northern Hemispheric (NH) boreal forests are highest). The annual-mean boundarylayer plot (Fig. 3a) shows $\mathrm{H}_{2} \mathrm{SO}_{4}$ more than doubling in tropical forests due to the addition of $\mathrm{CI}+\mathrm{SO}_{2}$ chemistry. The large fractional change in $\mathrm{H}_{2} \mathrm{SO}_{4}$ above the tropical forests is for two reasons: (1) there is a large isoprene source in these regions resulting in a large source of alkenes for production of CI, and (2) the OH concentrations are very low in these regions (Fig. 4) due to isoprene acting as a net $\mathrm{OH}$ sink in the GEOS-Chem chemistry scheme, meaning that the conversion of $\mathrm{SO}_{2}$ to $\mathrm{H}_{2} \mathrm{SO}_{4}$ is slow in these regions in the BASE simulation. The annual-average changes in $\mathrm{H}_{2} \mathrm{SO}_{4}$ in the $\mathrm{NH}$ bo-

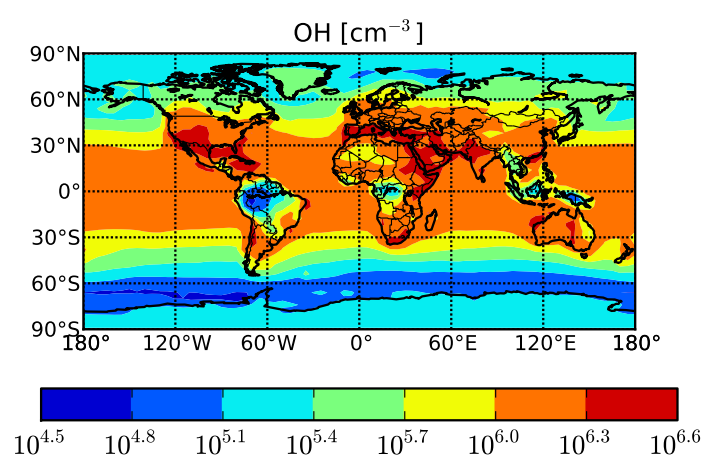

Fig. 4. Annual-mean boundary-layer $\mathrm{OH}$ concentrations in the BBASE simulation.

real and broad-leaf (e.g. southeastern US) forest regions are generally $10-25 \%$ increases. The $\mathrm{H}_{2} \mathrm{SO}_{4}$-enhancement region extends from the boreal forests into the Arctic where $\mathrm{OH}$ concentrations are low, particularly outside of the summer. The annual-average zonal-mean plot (Fig. 3b) shows that most of the $\mathrm{H}_{2} \mathrm{SO}_{4}$ enhancement is in the boundary layer due to the short lifetime (several hours to $\sim 1$ day) of the CI precursor gases. There is some enhancement in the tropical tropopause region due to transport of CI precursors, ozone and $\mathrm{SO}_{2}$ in deep convection.

In July (Fig. 3c, d), the $\mathrm{H}_{2} \mathrm{SO}_{4}$ enhancements in the tropics due to $\mathrm{CI}+\mathrm{SO}_{2}$ chemistry are nearly identical to the annualmean plots. On the other hand, the NH forests show a much larger sensitivity of $\mathrm{H}_{2} \mathrm{SO}_{4}$ concentrations to CI chemistry due to increased isoprene and monoterpene emissions in the 
(a) N3 BL \% change

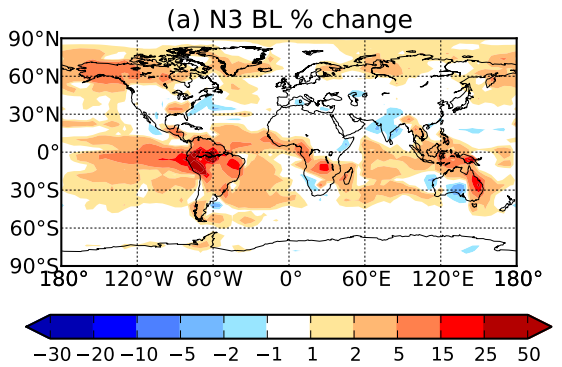

(c) N40 BL \% change

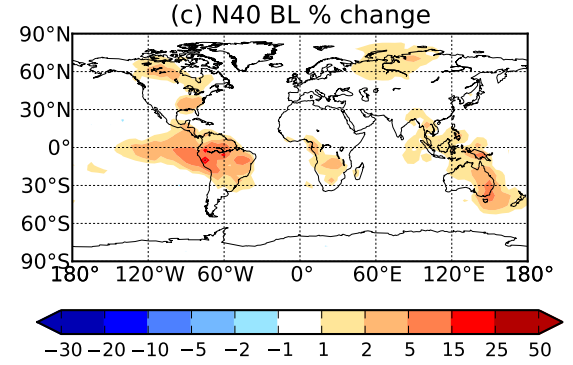

(b) N10 BL \% change

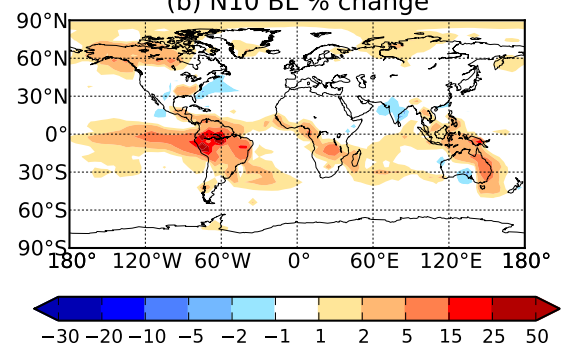

(d) N80 BL \% change

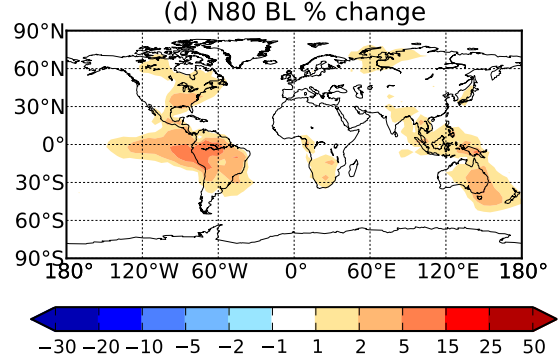

Fig. 5. The annual-mean boundary-layer change in $N 3,10,40$ and 80 due to the addition of $\mathrm{CI}+\mathrm{SO}_{2}$ chemistry (BASE-CI-BASE).

summer. $\mathrm{H}_{2} \mathrm{SO}_{4}$ concentrations change by over $100 \%$ in the southeastern US and by over $50 \%$ in many regions of the boreal forests, which means that $\mathrm{CI}+\mathrm{SO}_{2}$ is responsible for about $50 \%$ and $35 \%$ of the $\mathrm{H}_{2} \mathrm{SO}_{4}$ in the BASE-CI simulation in these regions, respectively. This increase in the boreal forest regions is slightly lower than the estimates of the summertime $\mathrm{H}_{2} \mathrm{SO}_{4}$ enhancements due to CI chemistry calculated by Boy et al. (2012), where $\mathrm{CI}+\mathrm{SO}_{2}$ chemistry was found to explain up to $50 \%$ of the gas-phase $\mathrm{H}_{2} \mathrm{SO}_{4}$ production in Hyytiälä, Finland and Hohenpeissenberg, Germany (as opposed to $\sim 35 \%$ in this study) even though a faster $\mathrm{CI}+\mathrm{SO}_{2}$ rate constant for large CIs was used here than in their work. This lower sensitivity in our model may be due to the coarse horizontal and vertical resolution of our global model compared to their local 0-D and 1-D models (that explicitly resolve the alkene-rich forest regions) used for their analysis. Nevertheless, it is possible that our estimates are not actually a sufficient upper bound for $\mathrm{H}_{2} \mathrm{SO}_{4}$ production through $\mathrm{CI}+\mathrm{SO}_{2}$ chemistry, and we will discuss this possibility in our conclusions. In July, the $\mathrm{H}_{2} \mathrm{SO}_{4}$ is enhanced by high percentages over Antarctica throughout the entire troposphere due to CI chemistry. This high sensitivity is due to extremely low $\mathrm{OH}$ and $\mathrm{H}_{2} \mathrm{SO}_{4}$ concentrations in the absence of CI chemistry. Although there is a large fractional change in Antarctica, the absolute change in this location is negligible, and CI chemistry has virtually no impact on the particle concentrations in this region (discussed next).

The $\mathrm{H}_{2} \mathrm{SO}_{4}$ differences between the XSOA and XSOA-CI cases (not shown) are nearly identical to Fig. 3. While the $\mathrm{H}_{2} \mathrm{SO}_{4}$ concentrations in XSOA are lower than BASE due to a larger condensation sink for $\mathrm{H}_{2} \mathrm{SO}_{4}$ in XSOA (and a similar difference for XSOA-CI versus BASE-CI), the fractional changes in $\mathrm{H}_{2} \mathrm{SO}_{4}$ between XSOA and XSOA-CI are similar to the fractional changes between BASE and BASE-CI.

It would be useful to evaluate the model-predicted $\mathrm{H}_{2} \mathrm{SO}_{4}$ concentrations against field observations (e.g. at Hyytiälä, Finland where these observations have been performed over extended time periods (Riipinen et al., 2011) to determine if the $\mathrm{CI}+\mathrm{SO}_{2}$ chemistry improves modeled $\mathrm{H}_{2} \mathrm{SO}_{4}$ concentrations. However, (1) the model overpredicts $\mathrm{H}_{2} \mathrm{SO}_{4}$ by a factor of 2 at Hyytiälä even without $\mathrm{CI}+\mathrm{SO}_{2}$ chemistry (likely because the large model grid box also includes cities and source regions, and there are uncertainties in the condensation sink), and (2) the modeled $\mathrm{H}_{2} \mathrm{SO}_{4}$ is more sensitive to the condensation sink ( $80 \%$ reduction in $\mathrm{H}_{2} \mathrm{SO}_{4}$ concentrations at Hyytiälä due to the addition of the extra $100 \mathrm{Tg}$ of SOA per year in the XSOA simulation) than the $\mathrm{CI}+\mathrm{SO}_{2}$ chemistry ( $25 \%$ increase in $\mathrm{H}_{2} \mathrm{SO}_{4}$ at Hyytiälä). Similarly, uncertainties in the accommodation coefficient and primary emissions would also cause uncertainties in the condensation sink. Thus, we were not able to gain any useful information about $\mathrm{CI}+\mathrm{SO}_{2}$ chemistry on improving $\mathrm{H}_{2} \mathrm{SO}_{4}$ concentrations in our model. On the other hand, the study of Boy et al. (2012), which simulated the local conditions explicitly with constrained condensation sinks and $\mathrm{SO}_{2}$ concentrations, did predict that $\mathrm{CI}+\mathrm{SO}_{2}$ chemistry was needed for the closure of $\mathrm{H}_{2} \mathrm{SO}_{4}$ concentrations. There is no evidence from our current study to either support or refute their conclusions, so we defer to their study as the current best estimate of the role of $\mathrm{CI}+\mathrm{SO}_{2}$ in generating $\mathrm{H}_{2} \mathrm{SO}_{4}$.

Figures 5 and 6 show the annual-mean and July-mean, respectively, boundary-layer changes in N3,N10,N40 and $N 80$ (the total number of particles larger than $3 \mathrm{~nm}, 10 \mathrm{~nm}$, $40 \mathrm{~nm}$ and $80 \mathrm{~nm}$, respectively) due to $\mathrm{CI}+\mathrm{SO}_{2}$ chemistry (BASE-CI - BASE). $N 40$ and $N 80$ represent a rough bound 
(a) N3 BL \% change

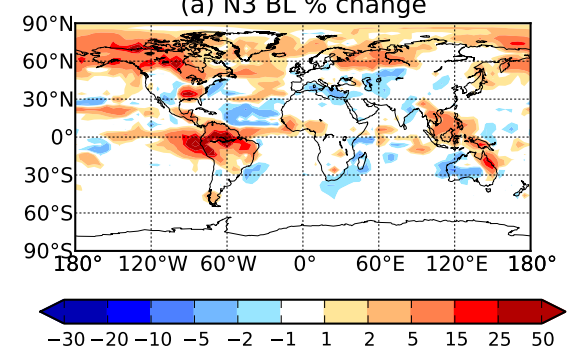

(c) $\mathrm{N} 40 \mathrm{BL} \%$ change

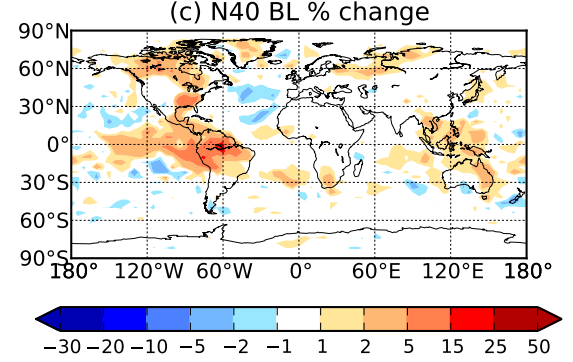

(b) N10 BL \% change

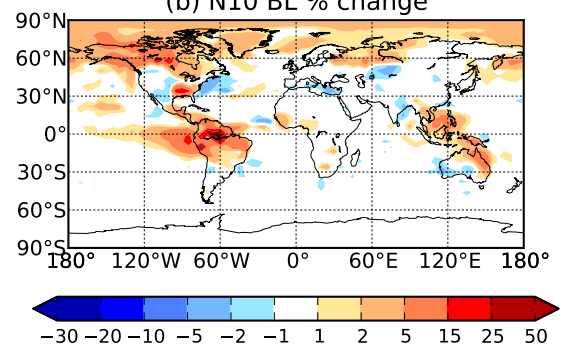

(d) N80 BL \% change

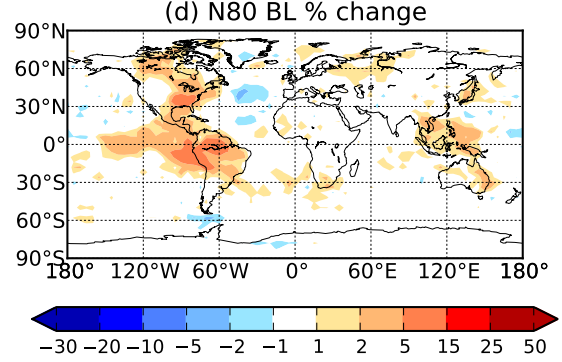

Fig. 6. The July-mean boundary-layer change in $N 3,10,40$ and 80 due to the addition of $\mathrm{CI}+\mathrm{SO}_{2}$ chemistry (BASE-CI-BASE).

for the $\mathrm{CCN}$ concentrations for most clouds. Similar to the enhancements in $\mathrm{H}_{2} \mathrm{SO}_{4}$ concentrations due to $\mathrm{CI}$ chemistry, the largest annually averaged $N$ enhancements (Fig. 5) for all size ranges are in the tropics. The enhancements are particularly large in the Amazon, where $N 3$ is enhanced by CI chemistry by over $25 \%$, and CCN are enhanced by $5-15 \%$. Outside of the tropics, the enhancements are more minor, where $N 3$ is nearly always less than a $15 \%$ enhancement, and CCN enhancements are generally less than $2 \%$ except for the southeast US for both $N 40$ and $N 80$ and part of Canada for $N 40$. There are a few regions where the addition of CI chemistry causes a decrease in $N 3$ and $N 10$. These are due to chemical feedbacks in $\mathrm{SO}_{2}$ and $\mathrm{OH}$ concentrations due to the CI chemistry and microphysical feedbacks due to changes in aerosol surface area.

The July averages (Fig. 6) show a stronger signal in the $\mathrm{NH}$ forested regions due to the larger source of CI precursors (isoprene and monoterpenes) as well as more noise due to the shorter averaging period. $N 3$ are enhanced by over $15 \%$ in many parts of Canada and southeastern US and over $5 \%$ in northeastern Europe. In general, the enhancements in $N 40$ and $N 80$ are about a factor of 3 lower due to microphysical dampening (and do not exceed $5 \%$ in the $\mathrm{NH}$ outside of the southeastern US) that will be discussed shortly.

Figure 7 shows the annual- and zonal-mean change in $N 3, N 10, N 40$ and $N 80$ concentrations due to CI chemistry (BASE-CI - BASE), and unlike the similar plots for $\mathrm{H}_{2} \mathrm{SO}_{4}$ (Fig. $3 \mathrm{~b}$ and d), the influence of the tropical CIs extend to the upper troposphere due to deep convection. The enhancements in the different size ranges show that small particles that nucleated in the tropical BL are transported to the upper troposphere by deep convection (the enhancements in $\mathrm{H}_{2} \mathrm{SO}_{4}$ in the upper troposphere were minor (Fig. $3 b$ and d), but may have contributed to the enhancements in $N 3$ there also). The small particles then grow to larger sizes via condensation in the upper troposphere and during transport. Thus, the $\mathrm{CI}$ chemistry contributes to more than $1 \%$ enhancements in $\mathrm{CCN}$ concentrations throughout much of the free troposphere.

The differences in $N 3, N 10, N 40$ and $N 80$ between XSOA-CI and XSOA are very similar to the differences between BASE-CI and BASE (not shown). Although the changes in $N$ are significant between BASE and XSOA (and BASE-CI and XSOA-CI), the relative influence of CI chemistry is similar.

Figures 3 and 5-7 show that although $\mathrm{H}_{2} \mathrm{SO}_{4}$ concentrations increase by over $10 \%$ due to $\mathrm{CI}$ chemistry throughout the forested boundary layer (and over $100 \%$ in the tropics and over $50 \%$ in the boreal summer), the annually averaged $\mathrm{CCN}$ increase is generally less than $1 \%$ in the boundary layer outside of the tropics (exceptions are in some NH forests, exceeding $2 \%$ in several locations). Even in the Amazon, where the $\mathrm{H}_{2} \mathrm{SO}_{4}$ concentrations more than doubled due to CI chemistry, the CCN concentrations only increased by 5$15 \%$. Thus, there is a strong microphysical dampening of changes in $\mathrm{CCN}$ to changes in $\mathrm{H}_{2} \mathrm{SO}_{4}$ in these locations. Although $\mathrm{H}_{2} \mathrm{SO}_{4}$ contributes to both nucleation and growth, the growth of particles in the forested boundary layer (where CI chemistry is important) in measurements (e.g. Riipinen et al., 2011) and in GEOS-Chem-TOMAS (Westervelt et al., 2012) is dominated by SOA. At Hyytiälä, Finland, the measurements show and model predicts that SOA condensation is responsible for over $90 \%$ of the particle growth. If $90 \%$ of the condensible material in a region is SOA and the remaining $10 \%$ is $\mathrm{H}_{2} \mathrm{SO}_{4}$, a $50 \%$ increase in $\mathrm{H}_{2} \mathrm{SO}_{4}$ due to $\mathrm{CI}+\mathrm{SO}_{2}$ chemistry only represents a $\sim 5 \%$ increase in condensible 

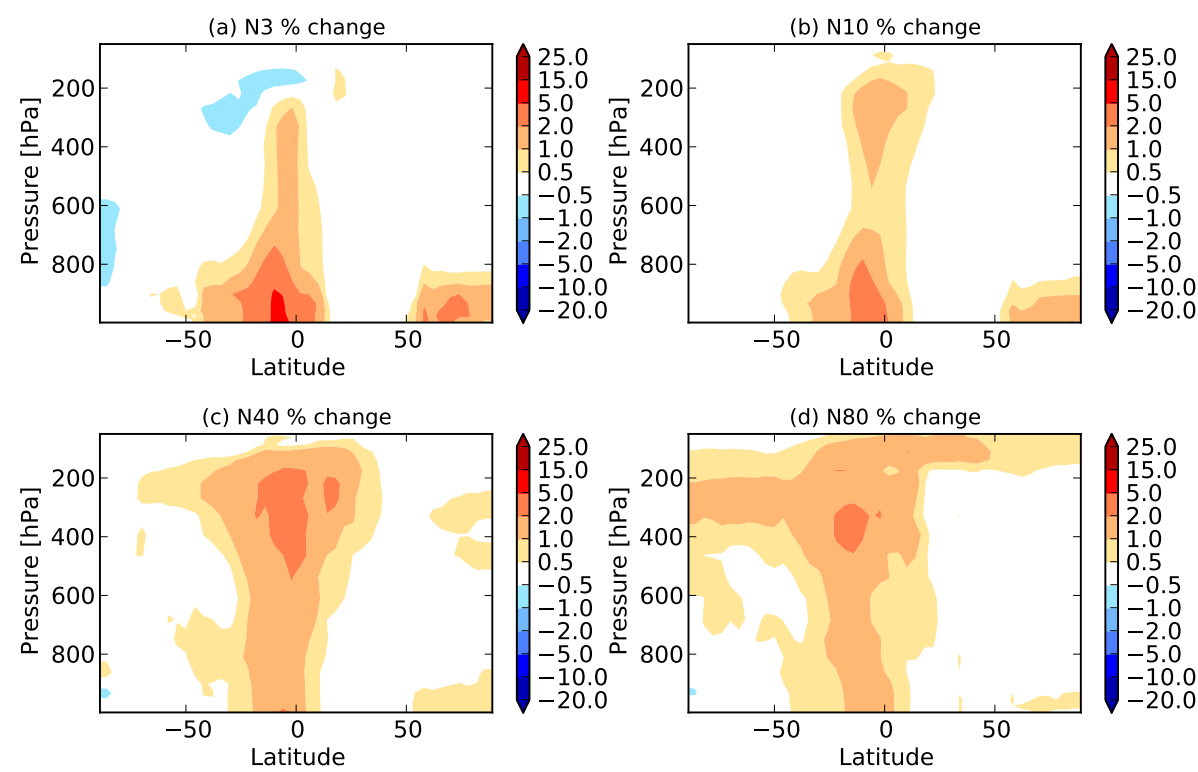

Fig. 7. The annual- and zonal-mean change in $N 3,10,40$ and 80 due to the addition of $\mathrm{CI}+\mathrm{SO}_{2}$ chemistry (BASE-CI-BASE).

material. Thus, the enhancement in $\mathrm{H}_{2} \mathrm{SO}_{4}$ has only a minor influence on the growth of the particles. Nucleation, on the other hand, is linear with $\mathrm{H}_{2} \mathrm{SO}_{4}$ concentrations in the boundary layer in the model (i.e. Fig. $3 \mathrm{a}$ and $\mathrm{c}$ also show the relative change in nucleation rates due to $\mathrm{CI}$ chemistry), and a $50 \%$ increase in $\mathrm{H}_{2} \mathrm{SO}_{4}$ due to $\mathrm{CI}+\mathrm{SO}_{2}$ chemistry represents a $50 \%$ increase in nucleation. However, the fractional change in $\mathrm{CCN}$ is strongly dampened to fractional changes in nucleation rate, which has been shown in several modeling studies (Makkonen et al., 2009; Pierce and Adams, 2009b, c; SnowKropla et al., 2011; Spracklen et al., 2008; Wang and Penner, 2009). This dampening occurs because an increase in the nucleation rate increases the total surface area of particles. The condensation and coagulation sinks are both roughly proportional to the surface area, so (1) the growth rates are inversely proportional to the change in condensation sink since the condensible material is spread across more particle surface area, and (2) the coagulational loss rates of the new particles are proportional to the coagulation sink. Thus, an increase in the nucleation rate (in the absence of a significant increase in condensible material) reduces the probability of particles surviving to reach $\mathrm{CCN}$ sizes due to increased coagulational losses and longer growth times (Pierce and Adams, 2007, 2009c; Westervelt et al., 2012), and in this study, fractional changes in $\mathrm{CCN}$ are significantly smaller than fractional changes in $\mathrm{H}_{2} \mathrm{SO}_{4}$.

The global boundary-layer averaged change in CCN (both $N 40$ and N80) was just under $1 \%$ between the BASE and BASE-CI simulations as well as between the XSOA and XSOA-CI simulations. The tropospheric-averaged changes in $\mathrm{CCN}$ were also just under $1 \%$. This globally averaged $\mathrm{CCN}$ sensitivity to $\mathrm{CI}+\mathrm{SO}_{2}$ chemistry is significantly lower than the sensitivity in $\mathrm{CCN}$ predictions to uncertainties in nucleation mechanisms (Merikanto et al., 2009; Pierce and Adams, 2009c; Reddington et al., 2011; Spracklen et al., 2008; Wang and Penner, 2009), SOA amount (Pierce and Adams, 2009c; Spracklen et al., 2008), primary emissions amount (Adams and Seinfeld, 2003; Pierce and Adams, 2006, 2009c; Reddington et al., 2011; Spracklen et al., 2011a) and size (Pierce and Adams, 2006, 2007; Reddington et al., 2011; Spracklen et al., 2011a), SOA condensational behavior (Riipinen et al., 2011) and wet deposition (Croft et al., 2012). Many of these other uncertain factors lead to $\mathrm{CCN}$ uncertainties larger than $10 \%$. Even if the simulations tested here do not represent a true upper bound for the impact of $\mathrm{CI}+\mathrm{SO}_{2}$ chemistry (e.g. the sensitivity of $\mathrm{H}_{2} \mathrm{SO}_{4}$ to $\mathrm{CI}+\mathrm{SO}_{2}$ chemistry was larger in Boy et al., 2012), the effect of $\mathrm{CI}+\mathrm{SO}_{2}$ chemistry on $\mathrm{CCN}$ would need to be an orderof-magnitude larger globally than predicted here in order to compete with some of the uncertain parameters listed above. Similarly, we did not test the sensitivity of $\mathrm{CCN}$ changes to $\mathrm{CI}+\mathrm{SO}_{2}$ chemistry under different nucleation-rate, primaryemissions or deposition assumptions; however, while uncertainties in each of these assumptions affect the $\mathrm{CCN}$ predictions, their effect on the sensitivity of $\mathrm{CCN}$ to $\mathrm{CI}+\mathrm{SO}_{2}$ chemistry is likely minimal (as was the case with the XTRASOA simulations, where $\mathrm{CCN}$ changed greatly due to the additional SOA, but the sensitivity of $\mathrm{CCN}$ to $\mathrm{CI}+\mathrm{SO}_{2}$ chemistry did not greatly change). Thus, while the $\mathrm{CI}+\mathrm{SO}_{2}$ chemistry is predicted to be important for $\mathrm{CCN}$ in some locations, particularly the Amazon, improving our understanding of $\mathrm{CI}+\mathrm{SO}_{2}$ chemistry will likely not significantly improve our estimates of CCN globally. 

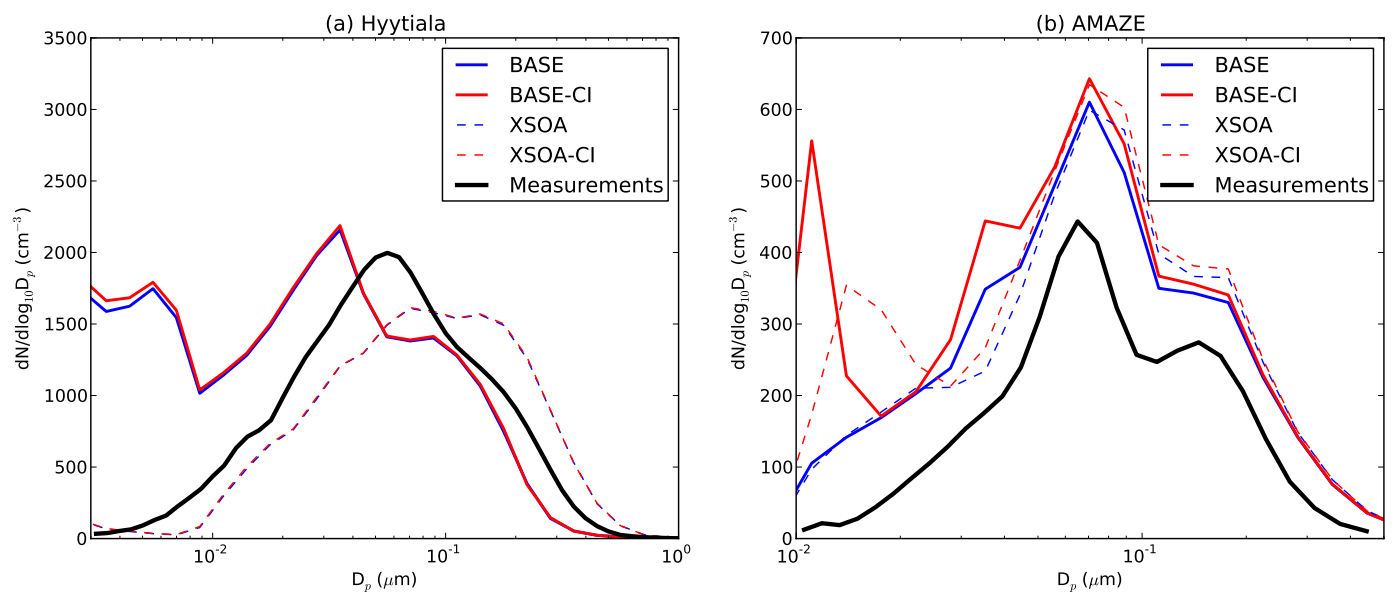

Fig. 8. (a) Measured and modelled (BASE, BASE-CI, XSOA and XSOA-CI) annual-mean aerosol size distribution at Hyytiälä for 2001. (b) The same but for the AMAZE campaign in the central Amazon during February and March.

\subsection{Comparison to size distribution measurements}

In Fig. 8, we evaluate the model size distributions in two locations that are both affected by the CI chemistry, Hyytiälä, Finland, and the AMAZE field station in the central Amazon, Brazil. Figure 8a shows the annual-average size distributions at Hyytiälä, Finland $\left(61^{\circ} 51^{\prime} \mathrm{N}, 24^{\circ} 17^{\prime}\right.$ E, $181 \mathrm{~m}$ a.s.l., Hari and Kulmala, 2005; Riipinen et al., 2011) predicted by the BASE, BASE-CI, XSOA and XSOA-CI simulations as well as the average-size distribution measured 2001 (the same year as the simulations). The simulated size distributions show a much larger sensitivity to the additional SOA (i.e. the difference between BASE and XSOA) than the sensitivity to the CI chemistry. The size distribution is biased towards smaller sizes in the BASE and BASE-CI simulations and biased towards larger sizes in the XSOA and XSOA-CI simulations. It appears that the model could best match the measured size distribution in Hyytiälä if a smaller amount of extra SOA than $100 \mathrm{Tg} \mathrm{yr}^{-1}$ was used. A more detailed and general evaluation on the additional SOA (beyond the $\mathrm{CI}+\mathrm{SO}_{2}$ context) is currently being performed; however, it is clear that uncertainties in the amount of SOA have a much larger affect on the size distribution and $\mathrm{CCN}$ in Hyytiälä than CI chemistry, and any error in the representation of CI chemistry will have little effect on the performance of the model in the Hyytiälä grid box.

Figure $8 \mathrm{~b}$ shows the same values as Fig. $8 \mathrm{a}$, but for the central Amazon $\left(02^{\circ} 36^{\prime} \mathrm{S}, 60^{\circ} 13^{\prime} \mathrm{W}, 110 \mathrm{~m}\right.$ a.s.l.) in Brazil during the AMAZE campaign (Martin et al., 2010). The AMAZE campaign took place during February and March 2008, and the model data plotted are for February and March 2001. All model simulations overpredict the size distribution by $50-100 \mathrm{~cm}^{-3}$ throughout all sizes (with a few exceptions in the nucleation/Aitken modes where model biases are even higher). In the central Amazon, there is a much smaller sensitivity to extra SOA correlated with anthropogenic $\mathrm{CO}$ emis- sion than in Hyytiälä due to the remoteness of the AMAZE station. Conversely, the sensitivity to CI chemistry is much larger than in Hyytiälä; thus, the uncertainties in the size distribution due to the two factors are similar. The CI chemistry causes significant (>25\%) increases in the number of nucleation/Aitken-mode particles, which is consistent with the Amazon region in Fig. 5a and b. However, the errors in the modeled size distribution are larger than could be explained by errors in CI chemistry. Therefore, some other source of error (e.g. primary emissions, biogenic SOA or unresolved sub-grid variability) must be responsible for the model bias. Even in the region with the strongest effect of $\mathrm{CI}+\mathrm{SO}_{2}$ chemistry, improvement of our representation of this chemistry would not significantly improve model performance.

\subsection{Aerosol indirect effect}

Figure 9 shows the annual mean cloud albedo AIE change due to the addition of $\mathrm{CI}+\mathrm{SO}_{2}$ chemistry to the model (radiative perturbation between the BASE-CI and BASE cases). Throughout most of the globe, the AIE change is very small $\left(<0.1 \mathrm{~W} \mathrm{~m}^{-2}\right)$, as would be expected by the small changes in $N 40$ and $N 80$ throughout most of the boundary layer. The strongest cooling due to the $\mathrm{CI}+\mathrm{SO}_{2}$ chemistry occurs over South America and to the west of Peru, where there Amazon-influenced CCN increases meet the persistent susceptible marine stratocumulus clouds of the eastern subtropical South Pacific ocean. In this region, the AIE changes exceed $-0.5 \mathrm{~W} \mathrm{~m}^{-2}$ in some locations. There is also some minor cooling in other subtropical marine cloud regions, over the South Atlantic and the eastern coast of Australia. Overall, the regions of cooling occupy a small fraction of Earth, so the global annual mean AIE change due to the inclusion of CI chemistry is only $-0.031 \mathrm{~W} \mathrm{~m}^{-2}$ for the BASE case (and $-0.034 \mathrm{~W} \mathrm{~m}^{-2}$ for the XSOA case, not 


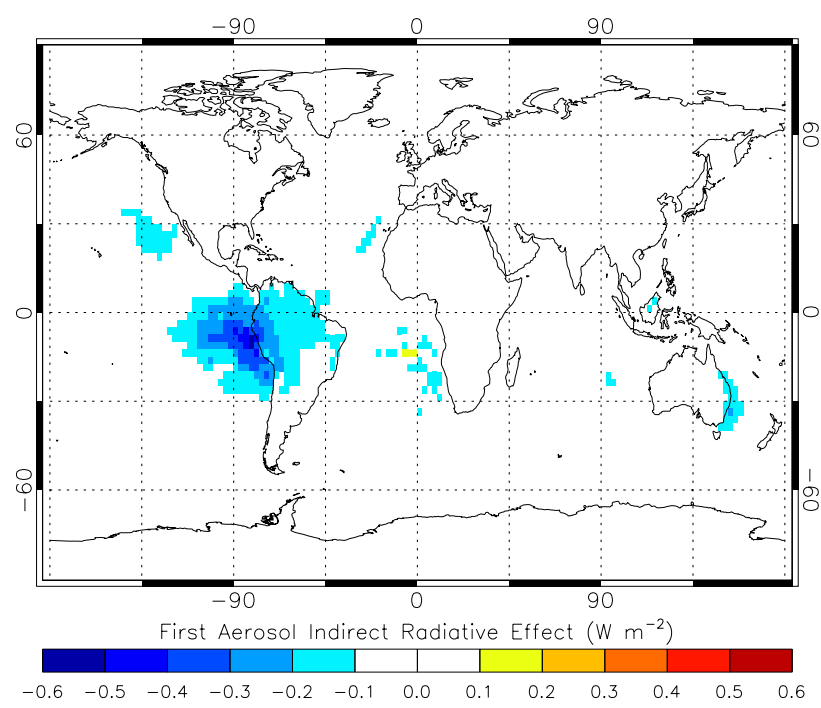

Fig. 9. Annual-mean cloud albedo AIE due to inclusion of $\mathrm{CI}+\mathrm{SO}_{2}$ chemistry with an assumed updraft velocity of $0.2 \mathrm{~m} \mathrm{~s}^{-1}$ (radiative perturbation between the BASE and BASE-CI simulations).

shown but similar spatial patterns) when the updraft velocities are assumed to be $0.2 \mathrm{~m} \mathrm{~s}^{-1}$. When the updraft velocities are varied between 0.1 and $0.5 \mathrm{~m}^{-1}$, the range of AIE was -0.025 to $-0.031 \mathrm{~W} \mathrm{~m}^{-2}$ for the BASE case (and -0.028 to $-0.036 \mathrm{~W} \mathrm{~m}^{-2}$ for XSOA). As these estimates are only for the cloud albedo AIE, the total AIE may be higher if aerosol lifetime effects were included. Similar to the results with $\mathrm{CCN}$, this cloud albedo AIE change is significantly smaller than the uncertainties due to nucleation mechanisms (Pierce and Adams, 2009c; Wang and Penner, 2009; Kazil et al., 2010), SOA amount (Pierce and Adams, 2009c), primary emissions amount (Adams and Seinfeld, 2003; Pierce and Adams, 2009c; Spracklen et al., 2011a) and size (Bauer et al., 2010; Spracklen et al., 2011a), SOA condensational behavior (Riipinen et al., 2011) and wet deposition (Croft et al., 2012).

\section{Conclusions}

In this study, we tested the sensitivity of the reaction of stabilized Criegee intermediates (CIs) with $\mathrm{SO}_{2}$ on presentday $\mathrm{H}_{2} \mathrm{SO}_{4}$, total aerosol number, and $\mathrm{CCN}$ concentrations as well as the cloud albedo aerosol indirect effect (AIE). Aerosol size distributions were predicted with and without $\mathrm{CI}+\mathrm{SO}_{2}$ chemistry in the GEOS-Chem-TOMAS global aerosol microphysics model. The production of CIs from the ozonolysis of isoprene, methyl vinyl ketone, methacrolein, propene, and monoterpenes (treated as if they were $\alpha$-pinene) were added to the model. CIs were lost by reaction with $\mathrm{CO}$, $\mathrm{NO}, \mathrm{NO}_{2}, \mathrm{H}_{2} \mathrm{O}$ and $\mathrm{SO}_{2}$. We used the fast $\mathrm{CI}+\mathrm{SO}_{2}$ rates measured by Welz et al. (2012) in an attempt to provide an upper bound for $\mathrm{CI}+\mathrm{SO}_{2}$ chemistry.
The ozonolysis of isoprene and its products (methyl vinyl ketone, methacrolein) represented about $62 \%$ of the CI production, with the ozonolysis of monoterpenes representing $25 \%$ and the rest by the ozonolysis of propene. Water vapor was the dominant loss for CIs globally $(96.6 \%)$, and $\mathrm{SO}_{2}$ represented most of the remaining loss $(2.9 \%)$. However, $\mathrm{SO}_{2}$ was a more significant sink of CIs in the polluted and/or dry $\mathrm{NH}$ regions (up to $60 \%$ in some regions). Because we used the fast Welz et al. (2012) rate constant for all $\mathrm{CI}+\mathrm{SO}_{2}$ reactions, these estimates of $\mathrm{CI}+\mathrm{SO}_{2}$ were likely an upper bound, and could be over an order-of-magnitude lower if other published rate constants were used. We also note the there are significant uncertainties on the rate constant of $\mathrm{CI}+\mathrm{H}_{2} \mathrm{O}$, leading to large uncertainties on the atmospheric fate of $\mathrm{CI}$ radicals.

The addition of the $\mathrm{CI}+\mathrm{SO}_{2}$ chemistry increased the production of $\mathrm{H}_{2} \mathrm{SO}_{4}$ globally by $4 \%$. However, the $\mathrm{H}_{2} \mathrm{SO}_{4}$ increases were driven almost entirely by increases over forested continental regions with large fluxes of biogenic alkene emissions. The annually averaged $\mathrm{H}_{2} \mathrm{SO}_{4}$ increases were over $100 \%$ in the tropics and were more than $10 \%$ in mid-latitude forests (though over $50 \%$ in many mid-latitude forests in July). The increases in $N 3, N 10, N 40$ and $N 80$ (the total particle number with diameters larger than 3,10,40 and $80 \mathrm{~nm}$, respectively) due to the addition of CI chemistry were generally co-located with, but were much smaller than, the increases in $\mathrm{H}_{2} \mathrm{SO}_{4}$. The annually averaged changes in $\mathrm{CCN}(N 40$ and $N 80)$ were less than $25 \%$ in the tropics and less than $5 \%$ in most mid-latitude locations. In July, when biogenic alkene emissions from mid-latitude forests are at their peak, many mid-latitude regions showed up to a $15 \%$ sensitivity in $\mathrm{CCN}$ due to $\mathrm{CI}+\mathrm{SO}_{2}$ chemistry. The relatively small sensitivity of CCN compared to the larger sensitivity of $\mathrm{H}_{2} \mathrm{SO}_{4}$ to $\mathrm{CI}$ chemistry is due, in part, to CI chemistry generally being only important in forested locations where SOA (as opposed to $\mathrm{H}_{2} \mathrm{SO}_{4}$ ) is the dominant species contributing to ultrafine particle growth. Thus, increasing $\mathrm{H}_{2} \mathrm{SO}_{4}$ in these locations increased nucleation rates but did not significantly increase growth rates, and $\mathrm{CCN}$ were dampened to changes in $\mathrm{H}_{2} \mathrm{SO}_{4}$ similar to previous studies looking at the sensitivity of $\mathrm{CCN}$ to changes in the nucleation rate (Makkonen et al., 2009; Pierce and Adams, 2009b, c; Snow-Kropla et al., 2011; Spracklen et al., 2008; Wang and Penner, 2009).

The global-averaged boundary-layer and free-tropospheric changes to $\mathrm{CCN}$ due to the addition of $\mathrm{CI}+\mathrm{SO}_{2}$ chemistry were both less than $1 \%$, which is a significantly smaller $\mathrm{CCN}$ sensitivity than the uncertainty in $\mathrm{CCN}$ due to uncertainty in nucleation mechanisms (Merikanto et al., 2009; Pierce and Adams, 2009c; Reddington et al., 2011; Spracklen et al., 2008; Wang and Penner, 2009), SOA amount (Pierce and Adams, 2009c; Spracklen et al., 2008), primary emissions amount (Adams and Seinfeld, 2003; Pierce and Adams, 2006, 2009c; Reddington et al., 2011; Spracklen et al., 2011a) and size (Pierce and Adams, 2006, 2007; Reddington et al., 2011; Spracklen et al., 2011a), SOA condensational 
behavior (Riipinen et al., 2011) and wet deposition (Croft et al., 2012). Subsequently, the uncertainty in the cloud albedo AIE change due to $\mathrm{CI}+\mathrm{SO}_{2}$ chemistry was about $0.03 \mathrm{~W} \mathrm{~m}^{-2}$ (depending on the assumed updraft velocity and SOA assumption), which is also significantly less than the other model uncertainties described above. The simulations presented here may not be a true upper bound on the impact of $\mathrm{CI}+\mathrm{SO}_{2}$ chemistry on $\mathrm{CCN}$ and the AIE (e.g. we found a smaller sensitivity of $\mathrm{H}_{2} \mathrm{SO}_{4}$ to $\mathrm{CI}+\mathrm{SO}_{2}$ chemistry than Boy et al. (2012) at the two sites that they investigated). It is possible that the model sensitivity may be biased either low or high due to the coarse model resolution. At the two European sites investigated by Boy et al. (2012), the model-predicted sensitivity of $\mathrm{H}_{2} \mathrm{SO}_{4}$ concentrations to $\mathrm{CI}+\mathrm{SO}_{2}$ chemistry was biased low, which may have been due to not explicitly resolving the alkene-rich forested observation regions. On the other hand, the instant mixing of anthropogenic $\mathrm{SO}_{2}$ emissions with biogenic alkene emissions in the coarse grid boxes could lead to a larger fraction of anthropogenic $\mathrm{SO}_{2}$ being oxidized by CIs in the model than in reality, which could bias the model-predicted impacts of $\mathrm{CI}+\mathrm{SO}_{2}$ chemistry on $\mathrm{CCN}$ high (however, we have no evidence of this). Regardless, it would take an order-of-magnitude increase in the $\mathrm{CCN}$ sensitivity to $\mathrm{CI}+\mathrm{SO}_{2}$ chemistry to be similar in importance to many of the other uncertain model parameters listed above. Similarly, comparisons to size-distribution measurements at boreal-forest and tropical-forest locations showed that other model uncertainties dominated errors in the aerosol size distribution. Thus, we conclude that improvements in our understanding of $\mathrm{CI}+\mathrm{SO}_{2}$ chemistry would not lead to significant improvements in present-day $\mathrm{CCN}$ predictions. However, it is possible that $\mathrm{CI}+\mathrm{SO}_{2}$ chemistry has a stronger effect on pre-industrial CCN predictions (not tested here), and thus could be important for determining the radiative forcing change between pre-industrial and present-day. Additionally, a warmer future climate could bring additional biogenic alkene emissions, which may increase the fraction of $\mathrm{SO}_{2}$ that is oxidized by CIs. However, additional biogenic alkenes may also yield more SOA. Additional SOA coupled with potential future reductions in $\mathrm{SO}_{2}$ emissions would mean that $\mathrm{H}_{2} \mathrm{SO}_{4}$ would be even less important for ultrafine particle growth, and the sensitivity of $\mathrm{CCN}$ to $\mathrm{CI}+\mathrm{SO}_{2}$ chemistry could be even less than in the present day.

One possible outcome of $\mathrm{CI}+\mathrm{SO}_{2}$ chemistry that we did not explore here is the formation of stable sulfur-bearing secondary ozonides (Vereecken et al., 2012). As the addition of an $\mathrm{SO}_{2}$ to the CI could lead to a reduction in vapor pressure of the $\mathrm{CI}, \mathrm{SO}_{2}+\mathrm{CI}$ could lead to an increase in SOA and may be one of the reasons that anthropogenic pollution has been shown to increase the abundance of biogenic SOA (Spracklen et al., 2011b). If the reaction rates of Welz et al. (2012) are applied to $\mathrm{CI}+\mathrm{SO}_{2} \rightarrow$ stable sulfur-bearing secondary ozonide, and we assume that $0 \%$ of the $\mathrm{CI}$ would have formed SOA if it had not reacted with $\mathrm{SO}_{2}$ (an obvious underestimate) and $100 \%$ of the stable sulfur-bearing sec- ondary ozonide forms SOA, we find that the enhancement of SOA would be several to $10 \mathrm{~s}$ of $\mathrm{Tg} \mathrm{SOA} \mathrm{yr}{ }^{-1}$. While this calculation is likely an upper bound, it shows that $\mathrm{CI}+\mathrm{SO}_{2}$ chemistry might be important through this pathway, and this should be explored in future work.

Acknowledgements. We thank the Atlantic Computational Excellence Network (ACEnet) and the Canadian Foundation for Innovation (CFI) for the computing resources used in this study. We thank the Natural Sciences and Engineering Research Council (NSERC) of Canada and the Electric Power Research Institute (EPRI) for funding.

Edited by: V.-M. Kerminen

\section{References}

Adams, P. J. and Seinfeld, J. H.: Predicting global aerosol size distributions in general circulation models, J. Geophys. Res.-Atmos., 107, 4310-4370, doi:10.1029/2001JD001010, 2002.

Adams, P. J. and Seinfeld, J. H.: Disproportionate impact of particulate emissions on global cloud condensation nuclei concentrations, Geophys. Res. Lett., 30, 1210-1239, doi:10.1029/2002GL016303, 2003.

Albrecht, B. A.: Aerosols, cloud microphysics, and fractional cloudiness, Science, 245, 1227-1230, doi:10.1126/science.245.4923.1227, 1989.

Bauer, S. E., Menon, S., Koch, D., Bond, T. C., and Tsigaridis, K.: A global modeling study on carbonaceous aerosol microphysical characteristics and radiative effects, Atmos. Chem. Phys., 10, 7439-7456, doi:10.5194/acp-10-7439-2010, 2010.

Berglen, T. F., Berntsen, T. K., Isaksen, I. S. A., and Sundet, J. K.: A global model of the coupled sulfur/oxidant chemistry in the troposphere: The sulfur cycle, J. Geophys. Res.-Atmos., 109, D19310, doi:10.1029/2003JD003948, 2004.

Boy, M., Mogensen, D., Smolander, S., Zhou, L., Nieminen, T., Paasonen, P., Plass-Dülmer, C., Sipilä, M., Petäjä, T., Mauldin, L., Berresheim, H., and Kulmala, M.: Oxidation of $\mathrm{SO}_{2}$ by stabilized Criegee Intermediate ( $\mathrm{SCI}$ ) radicals as a crucial source for atmospheric sulphuric acid concentrations, Atmos. Chem. Phys. Discuss., 12, 27693-27736, doi:10.5194/acpd-12-276932012, 2012.

Calvert, J. R., Atkinson, R., Kerr, J. A., Madronich, S., Moortgat, G. K., Wallington, T. J., and Yarwood, G.: Mechanisms of Atmospheric Oxidation of the Alkenes, Oxford University Press, New York, 2000.

Charlson, R. J., Schwartz, S. E., Hales, J. M., Cess, R. D., Coakley, J. A., Hansen, J. E., and Hofman, D. J.: Climate forcing by anthropogenic aerosols, Science, 255, 423-430, doi:10.1126/science.255.5043.423, 1992.

Chin, M. A., Jacob, D. J., Gardner, G. M., Foreman-Fowler, M. S., Spiro, P. A., and Savoie, D. L.: A global three-dimensional model of tropospheric sulfate, J. Geophys. Res.-Atmos., 101, 1866718690, doi:10.1029/96JD01221, 1996.

Croft, B., Pierce, J. R., Martin, R. V., Hoose, C., and Lohmann, U.: Uncertainty associated with convective wet removal of entrained aerosols in a global climate model, Atmos. Chem. Phys., 12, 10725-10748, doi:10.5194/acp-12-10725-2012, 2012. 
Edwards, J. M. and Slingo, A.: Studies with a flexible new radiation code. I: Choosing a configuration for a large-scale model, Q. J. Roy. Meteor. Soc., 122, 689-719, doi:10.1002/qj.49712253107, 1996.

Forster, P., Ramaswamy, V., Artaxo, P., Berntsen, T., Betts, R., Fahey, D. W., Haywood, J., Lean, J., Lowe, D. C., Myhre, G., Nganga, J., Prinn, R., Raga, G., Schulz, M., and Dorland, R. V: Changes in atmospheric constituents and in radiative forcing, in Climate change 2007: the physical science basis. Contribution of working group I to the fourth assessment report of the intergovernmental panel on climate change, edited by: Solomon, S., Qin, D., Manning, M., Chen, Z., Marquis, M., Averyt, K. B., Tignor, M., and Miller, H. L., Cambridge University Press, Cambridge, United Kingdom and New York, NY, USA, 129-234, 2007.

Hari, P. and Kulmala, M.: Station for Measuring Ecosystem - Atmosphere Relations (SMEAR II), Boreal Environ. Res., 10, 315322, 2005.

Jenkin, M. E., Saunders, S. M., and Pilling, M. J.: The tropospheric degradation of volatile organic compounds: a protocol for mechanism development, Atmos. Environ., 31, 81-104, doi:10.1016/S1352-2310(96)00105-7, 1997.

Jimenez, J. L., Canagaratna, M. R., Donahue, N. M., Prevot, A. S. H., Zhang, Q., Kroll, J. H., DeCarlo, P. F., Allan, J. D., Coe, H., Ng, N. L., Aiken, A. C., Docherty, K. S., Ulbrich, I. M., Grieshop, A. P., Robinson, A. L., Duplissy, J., Smith, J. D., Wilson, K. R., Lanz, V. A., Hueglin, C., Sun, Y. L., Tian, J., Laaksonen, A., Raatikainen, T., Rautiainen, J., Vaattovaara, P., Ehn, M., Kulmala, M., Tomlinson, J. M., Collins, D. R., Cubison, M. J., Dunlea, E. J., Huffman, J. A., Onasch, T. B., Alfarra, M. R., Williams, P. I., Bower, K., Kondo, Y., Schneider, J., Drewnick, F., Borrmann, S., Weimer, S., Demerjian, K., Salcedo, D., Cottrell, L., Griffin, R., Takami, A., Miyoshi, T., Hatakeyama, S., Shimono, A., Sun, J. Y., Zhang, Y. M., Dzepina, K., Kimmel, J. R., Sueper, D., Jayne, J. T., Herndon, S. C., Trimborn, A. M., Williams, L. R., Wood, E. C., Middlebrook, A. M., Kolb, C. E., Baltensperger, U., and Worsnop, D. R.: Evolution of organic aerosols in the atmosphere, Science, 326, 1525-1529, doi:10.1126/science.1180353, 2009.

Jung, J. G., Adams, P. J., and Pandis, S. N.: Simulating the size distribution and chemical composition of ultrafine particles during nucleation events, Atmos. Environ., 40, 2248-2259, 2006.

Kazil, J., Stier, P., Zhang, K., Quaas, J., Kinne, S., O’Donnell, D., Rast, S., Esch, M., Ferrachat, S., Lohmann, U., and Feichter, J.: Aerosol nucleation and its role for clouds and Earth's radiative forcing in the aerosol-climate model ECHAM5-HAM, Atmos. Chem. Phys., 10, 10733-10752, doi:10.5194/acp-1010733-2010, 2010.

Koch, D., Jacob, D., Tegen, I., Rind, D., and Chin, M.: Tropospheric sulfur simulation and sulfate direct radiative forcing in the Goddard Institute for Space Studies general circulation model, J. Geophys. Res.-Atmos., 104, 23799-23822, doi:10.1029/1999JD900248, 1999.

Kulmala, M., Vehkamaki, H., Petajda, T., Dal Maso, M., Lauri, A., Kerminen, V. M., Birmili, W., and McMurry, P. H.: Formation and growth rates of ultrafine atmospheric particles: a review of observations, J. Aerosol Sci., 35, 143-176, doi:10.1016/j.jaerosci.2003.10.003, 2004.

Lee, Y. H. and Adams, P. J.: Evaluation of aerosol distributions in the GISS-TOMAS global aerosol microphysics model with re- mote sensing observations, Atmos. Chem. Phys., 10, 2129-2144, doi:10.5194/acp-10-2129-2010, 2010.

Lee, Y. H., Chen, K., and Adams, P. J.: Development of a global model of mineral dust aerosol microphysics, Atmos. Chem. Phys., 9, 2441-2458, doi:10.5194/acp-9-2441-2009, 2009.

Makkonen, R., Asmi, A., Korhonen, H., Kokkola, H., Järvenoja, S., Räisänen, P., Lehtinen, K. E. J., Laaksonen, A., Kerminen, V.M., Järvinen, H., Lohmann, U., Bennartz, R., Feichter, J., and Kulmala, M.: Sensitivity of aerosol concentrations and cloud properties to nucleation and secondary organic distribution in ECHAM5-HAM global circulation model, Atmos. Chem. Phys., 9, 1747-1766, doi:10.5194/acp-9-1747-2009, 2009.

Martin, S. T., Andreae, M. O., Althausen, D., Artaxo, P., Baars, H., Borrmann, S., Chen, Q., Farmer, D. K., Guenther, A., Gunthe, S. S., Jimenez, J. L., Karl, T., Longo, K., Manzi, A., Müller, T., Pauliquevis, T., Petters, M. D., Prenni, A. J., Pöschl, U., Rizzo, L. V., Schneider, J., Smith, J. N., Swietlicki, E., Tota, J., Wang, J., Wiedensohler, A., and Zorn, S. R.: An overview of the Amazonian Aerosol Characterization Experiment 2008 (AMAZE08), Atmos. Chem. Phys., 10, 11415-11438, doi:10.5194/acp10-11415-2010, 2010.

Mauldin, R. L., Berndt, T., Sipilä, M., Paasonen, P., Petäjä, T., Kim, S., Kurtén, T., Stratmann, F., Kerminen, V.-M., and Kulmala, M.: A new atmospherically relevant oxidant of sulphur dioxide, Nature, 488, 193-196, doi:10.1038/nature11278, 2012.

Merikanto, J., Spracklen, D. V., Mann, G. W., Pickering, S. J., and Carslaw, K. S.: Impact of nucleation on global CCN, Atmos. Chem. Phys., 9, 8601-8616, doi:10.5194/acp-9-8601-2009, 2009.

Nenes, A. and Seinfeld, J. H.: Parameterization of cloud droplet formation in global climate models, J. Geophys. Res.-Atmos, 108, 4415, doi:10.1029/2002JD002911, 2003.

Petters, M. D. and Kreidenweis, S. M.: A single parameter representation of hygroscopic growth and cloud condensation nucleus activity, Atmos. Chem. Phys., 7, 1961-1971, doi:10.5194/acp-71961-2007, 2007.

Pierce, J. R. and Adams, P. J.: Global evaluation of CCN formation by direct emission of sea salt and growth of ultrafine sea salt, J. Geophys. Res.-Atmos., 111, D06203, doi:10.1029/2005JD006186, 2006.

Pierce, J. R. and Adams, P. J.: Efficiency of cloud condensation nuclei formation from ultrafine particles, Atmos. Chem. Phys., 7, 1367-1379, doi:10.5194/acp-7-1367-2007, 2007.

Pierce, J. R. and Adams, P. J.: A Computationally Efficient Aerosol Nucleation/ Condensation Method: PseudoSteady-State Sulfuric Acid, Aerosol Sci. Tech., 43, 216-226, doi:10.1080/02786820802587896, 2009a.

Pierce, J. R. and Adams, P. J.: Can cosmic rays affect cloud condensation nuclei by altering new particle formation rates?, Geophys. Res. Lett., 36, 1-6, doi:10.1029/2009GL037946, 2009b.

Pierce, J. R. and Adams, P. J.: Uncertainty in global CCN concentrations from uncertain aerosol nucleation and primary emission rates, Atmos. Chem. Phys., 9, 1339-1356, doi:10.5194/acp-91339-2009, 2009c.

Pierce, J. R., Chen, K., and Adams, P. J.: Contribution of primary carbonaceous aerosol to cloud condensation nuclei: processes and uncertainties evaluated with a global aerosol microphysics model, Atmos. Chem. Phys., 7, 5447-5466, doi:10.5194/acp-75447-2007, 2007. 
Pierce, J. R., Theodoritsi, G., Adams, P. J., and Pandis, S. N.: Parameterization of the effect of sub-grid scale aerosol dynamics on aerosol number emission rates, J. Aerosol Sci., 40, 385-393, doi:10.1016/j.jaerosci.2008.11.009, 2009.

Pierce, J. R., Riipinen, I., Kulmala, M., Ehn, M., Petäjä, T., Junninen, H., Worsnop, D. R., and Donahue, N. M.: Quantification of the volatility of secondary organic compounds in ultrafine particles during nucleation events, Atmos. Chem. Phys., 11, 90199036, doi:10.5194/acp-11-9019-2011, 2011.

Rap, A., Spracklen, D. V., Bellouin, N., Carslaw, K. S., Schmidt, A., Scott, C. E., and Mann, G. W.: Natural aerosol direct and indirect radiative effects, Geophys. Res. Lett., submitted, 2013.

Reddington, C. L., Carslaw, K. S., Spracklen, D. V., Frontoso, M. G., Collins, L., Merikanto, J., Minikin, A., Hamburger, T., Coe, H., Kulmala, M., Aalto, P., Flentje, H., Plass-Dülmer, C., Birmili, W., Wiedensohler, A., Wehner, B., Tuch, T., Sonntag, A., O’Dowd, C. D., Jennings, S. G., Dupuy, R., Baltensperger, U., Weingartner, E., Hansson, H.-C., Tunved, P., Laj, P., Sellegri, K., Boulon, J., Putaud, J.-P., Gruening, C., Swietlicki, E., Roldin, P., Henzing, J. S., Moerman, M., Mihalopoulos, N., Kouvarakis, G., Ždímal, V., Zíková, N., Marinoni, A., Bonasoni, P., and Duchi, R.: Primary versus secondary contributions to particle number concentrations in the European boundary layer, Atmos. Chem. Phys., 11, 12007-12036, doi:10.5194/acp-11-12007-2011, 2011.

Riipinen, I., Pierce, J. R., Yli-Juuti, T., Nieminen, T., Häkkinen, S., Ehn, M., Junninen, H., Lehtipalo, K., Petäjä, T., Slowik, J., Chang, R., Shantz, N. C., Abbatt, J., Leaitch, W. R., Kerminen, V.-M., Worsnop, D. R., Pandis, S. N., Donahue, N. M., and Kulmala, M.: Organic condensation: a vital link connecting aerosol formation to cloud condensation nuclei $(\mathrm{CCN})$ concentrations, Atmos. Chem. Phys., 11, 3865-3878, doi:10.5194/acp-11-38652011, 2011.

Sihto, S.-L., Kulmala, M., Kerminen, V.-M., Dal Maso, M., Petäjä, T., Riipinen, I., Korhonen, H., Arnold, F., Janson, R., Boy, M., Laaksonen, A., and Lehtinen, K. E. J.: Atmospheric sulphuric acid and aerosol formation: implications from atmospheric measurements for nucleation and early growth mechanisms, Atmos. Chem. Phys., 6, 4079-4091, doi:10.5194/acp-6-4079-2006, 2006.

Snow-Kropla, E. J., Pierce, J. R., Westervelt, D. M., and Trivitayanurak, W.: Cosmic rays, aerosol formation and cloudcondensation nuclei: sensitivities to model uncertainties, Atmos. Chem. Phys., 11, 4001-4013, doi:10.5194/acp-11-4001-2011, 2011.

Sofen, E. D., Alexander, B., and Kunasek, S. A.: The impact of anthropogenic emissions on atmospheric sulfate production pathways, oxidants, and ice core $\Delta^{17} \mathrm{O}\left(\mathrm{SO}_{4}^{2-}\right)$, Atmos. Chem. Phys., 11, 3565-3578, doi:10.5194/acp-11-3565-2011, 2011.

Spracklen, D. V, Carslaw, K. S., Kulmala, M., Kerminen, V. M., Sihto, S. L., Riipinen, I., Merikanto, J., Mann, G. W., Chipperfield, M. P., Wiedensohler, A., Birmili, W., and Lihavainen, H.: Contribution of particle formation to global cloud condensation nuclei concentrations, Geophys. Res. Lett., 35, D06808, doi:10.1029/2007GL033038, 2008.
Spracklen, D. V., Carslaw, K. S., Pöschl, U., Rap, A., and Forster, P. M.: Global cloud condensation nuclei influenced by carbonaceous combustion aerosol, Atmos. Chem. Phys., 11, 9067-9087, doi:10.5194/acp-11-9067-2011, 2011a.

Spracklen, D. V., Jimenez, J. L., Carslaw, K. S., Worsnop, D. R., Evans, M. J., Mann, G. W., Zhang, Q., Canagaratna, M. R., Allan, J., Coe, H., McFiggans, G., Rap, A., and Forster, P.: Aerosol mass spectrometer constraint on the global secondary organic aerosol budget, Atmos. Chem. Phys., 11, 12109-12136, doi:10.5194/acp-11-12109-2011, 2011 b.

Trivitayanurak, W., Adams, P. J., Spracklen, D. V., and Carslaw, K. S.: Tropospheric aerosol microphysics simulation with assimilated meteorology: model description and intermodel comparison, Atmos. Chem. Phys., 8, 3149-3168, doi:10.5194/acp-83149-2008, 2008.

Twomey, S.: Pollution and the planetary albedo, Atmos. Environ., 8, 1251-1256, doi:10.1016/j.atmosenv.2007.10.062, 1974.

van Donkelaar, A., Martin, R. V., Leaitch, W. R., Macdonald, A. M., Walker, T. W., Streets, D. G., Zhang, Q., Dunlea, E. J., Jimenez, J. L., Dibb, J. E., Huey, L. G., Weber, R., and Andreae, M. O.: Analysis of aircraft and satellite measurements from the Intercontinental Chemical Transport Experiment (INTEX-B) to quantify long-range transport of East Asian sulfur to Canada, Atmos. Chem. Phys., 8, 2999-3014, doi:10.5194/acp-8-2999-2008, 2008.

Vehkamäki, H., Kulmala, M., Napari, I., Lehtinen, K. E. J., Timmreck, C., Noppel, M., and Laaksonen, A.: An improved parameterization for sulfuric acid-water nucleation rates for tropospheric and stratospheric conditions, J. Geophys. Res.-Atmos., 107, 4610-4622, doi:10.1029/2002JD002184, 2002.

Vereecken, L., Harder, H., and Novelli, A.: The reaction of Criegee intermediates with $\mathrm{NO}, \mathrm{RO}_{2}$, and $\mathrm{SO}_{2}$, and their fate in the atmosphere, Phys. Chem. Chem. Phys., 14, 14682-14695, doi:10.1039/c2cp42300f, 2012.

Wang, M. and Penner, J. E.: Aerosol indirect forcing in a global model with particle nucleation, Atmos. Chem. Phys., 9, 239-260, doi:10.5194/acp-9-239-2009, 2009.

Welz, O., Savee, J. D., Osborn, D. L., Vasu, S. S., Percival, C. J., Shallcross, D. E., and Taatjes, C. A.: Direct kinetic measurements of Criegee intermediate $\left(\mathrm{CH}_{2} \mathrm{OO}\right)$ formed by reaction of $\mathrm{CH}_{2} \mathrm{I}$ with $\mathrm{O}_{2}$, Science, 335, 204-207, doi:10.1126/science.1213229, 2012.

Westervelt, D. M., Riipinen, I., Pierce, J. R., Trivitayanurak, W., and Adams, P. J.: Formation and growth of nucleated particles: observational constraints on cloud condensation nuclei budgets, Atmos. Chem. Phys. Discuss., 12, 11765-11822, doi:10.5194/acpd-12-11765-2012, 2012. 